\title{
BERNARDINO DE VILLALPANDO Y LAS CONSTITUCIONES SINODALES DEL OBISPADO DE GUATEMALA (1566)
}

\author{
Mario Humberto Ruz \\ Centro de Estudios Mayas, IIFL, UNAM \\ Baltazar Hernández Vargas \\ Facultad de Filosofia y Letras, UNAM
}

El año de 1564 Bernardino de Villalpando fue presentado al Vaticano por Felipe II para ocupar la sede de Guatemala, vacante por la muerte de su primer diocesano, el célebre Francisco Marroquín. Nacido en Talavera de la Reina, el doctor en teología se desempeñaba desde abril de 1559 como obispo de Santiago de Cuba (González Dávila, 1982: 153), y fue su buena actuación al frente de esa mitra lo que le valió el cambio a Guatemala.

La fecha en que tomó posesión de la Diócesis sigue siendo confusa: fray Francisco Vázquez (1937, I: 184) apunta que se le hizo merced del Obispado el 9 de marzo de 1564, y Eguiara y Eguren (1986, II: 675) registra la toma de posesión el 19 de agosto de 1565, mientras que Estrada Monroy, tras criticar a sus predecesores, cita el Primer Libro de Cabildo para asegurar que lo hizo desde febrero de 1564 (1973, I: 151), pero se equivocó al leer la data, pues corresponde a febrero de 1566 (f. 101). ${ }^{1}$ De hecho, al revisar dicho libro encontramos que en agosto de 1564 el Cabildo seguía sesionando como Sede Vacante (f. 89) y el 12 de julio de 1565 se reunió para nombrar a quien habría de representar a la Diócesis en el Concilio a celebrarse en México en agosto (f. 97); imposible pensar que el obispo estuviese ausente en decisión tan trascendente en el caso de haber optado por no asistir personalmente al Concilio. Puesto que las actas se hallan en total desorden cronológico, habrá que esperar la totalidad de su paleografía para precisar la fecha, ${ }^{2}$ pero es claro que para el segundo semestre de 1565 Villalpando estaba ya en Guatemala.

Gobernar la nueva Diócesis no le resultó tarea sencilla, ya que amén de tener que cargar con el fantasma de la memoria de su célebre antecesor, ${ }^{3}$ apenas llegar emprendió una serie de medidas tendientes a fortalecer el poder episcopal, que le significaron diversos enfrentamientos con las poderosas órdenes mendicantes, cuyas prerrogativas intentó limitar. A ello ha de agregarse la peculiar situación que vivía Guatemala, pues dados los numerosos problemas administrativos se le despojó del rango de sede de la

\footnotetext{
' Su error fue basarse en la apostilla, que equivoca la fecha. No es éste sin duda el único dato confuso, como mero ejemplo señalemos que en la foja 90 Villalpando aparece aprobando lo acordado por el Cabildo en sesión del 2 de septiembre de 1564, pero tal aprobación se fecha el 5 de julio de 1566, bastante a posteriori.

2 Trabajamos ya en la edición de dicho libro (Ruz, De Paz y Vicencio, en preparación).

${ }^{3}$ Sobre el papel que jugó Marroquín en la institucionalización de la Iglesia guatemalteca, sigue siendo de valía el trabajo de O'Flaherty (1984).
} 
Audiencia a fines de 1563, adscribiéndose de nuevo a México, junto con Chiapas, Soconusco y El Salvador. ${ }^{4}$ El gobierno quedó bajo el juez de residencia Francisco Briceño desde el 12 de febrero de 1565, cuando se recibió la real cédula respectiva (MacLeod, op. cit.: 73; Vázquez, op. cit.: 184).

Si bien a los ojos de los cronistas conventuales (principal fuente de información sobre la época) la actuación del prelado fue poco menos que desastrosa -juicio que no es de extrañar procediendo de quien procede-, a siglos de distancia se antoja al menos en parte comprensible; para cuando don Bernardino se hizo cargo de ella, ciertamente no podría calificarse a la de Guatemala como una mitra consolidada. A más de su juventud, pesaba sobre ella el enorme poder de las órdenes religiosas (en particular domini$\cos$ y franciscanos, seguidos muy atrás por lo mercedarios), que controlaban en buena medida a la que acertadamente Van Oss calificó como "una república de frailes e indios". Si hacia 1555 los predicadores administraban 47 pueblos, los franciscanos 37 y los mercedarios seis -en su gran mayoría en las llamadas Tierras Altas, asiento privilegiado de los pueblos mayances-, los clérigos apenas controlaban cinco (1986: 38-45).

Frente a este virtual monopolio de las órdenes religiosas sobre los pueblos indios (en su mayoría congregados o reducidos por ellos mismos, cabe recordar), el obispo se encontraba, pues, en franca desventaja: gobernaba una Diócesis carente de rentas jugosas, contaba con pocos clérigos que le permitiesen consolidar la influencia episcopal y debía además lidiar con antiguas prebendas de las órdenes, que les dotaban de relativa autonomía. Entre las acciones tomadas por Villalpando a fin de subsanar tales problemas, se cuentan las que llevó a cabo para acrecentar las rentas del Obispado, a la vez que sanearlas, nombrando un nuevo mayordomo, don Juan de Roxas. Así, el 18 de abril de ese mismo 1564 "restableció el cobro por derechos de enterramientos de niños y de indios, así como los derechos de bautismo y ofrendas, disponiendo que se iría a mitad con el Cabildo", y un mes más tarde dispuso cambios en la administración de diversas parroquias del territorio salvadoreño (Estrada: ibid.).

El enfrentamiento se volvió frontal cuando Villalpando, basándose en una peculiar interpretación del reciente Concilio de Trento, ${ }^{5}$ cuyas disposiciones juzgó limitaban las facultades de los regulares en cuanto a su desempeño como curas, intentó circunscribir su papel en lo concerniente a la administración de los sacramentos. Retiró a algún dominico sus licencias para predicar y confesar (Remesal, 1988, II: 486), "e incluso se llegó a prohibir que se celebrase el santo sacrificio [de la misa] en todas las doctrinas de religiosos, si no se había celebrado antes la misa del templo parroquial" (Estrada, op.cit.: 155). Como veremos más adelante, de algunas de tales disposiciones (y otras más) se hacen eco las constituciones sinodales decretadas por obispo y Cabildo, que no ocultan por ejemplo el interés en alentar la participación de los fieles en los oficios celebrados en catedral, deslucidos a menudo por el apego que mostraban los feligreses en asistir a las funciones religiosas oficiadas en los conventos. Y junto con los fieles, los frailes se hacían de sus limosnas y pagos.

${ }^{4}$ El resto del territorio de la Audiencia, entonces llamada de Los Confines, se adscribió a Tierra Firme, poniéndose la sede en Panamá (Macleod, 1980).

${ }^{5}$ Decretis Concilii Tridentini in pravum sensum retortis ("Desfigurados los decretos del Concilio Tridentino con mala interpretación"), asienta Vázquez (op. cit.: 184). 
Siendo justos, la interpretación que hizo el prelado de las disposiciones tridentinas no era totalmente errada (como lo muestra, por cierto, el que el papa tuviese que dar un breve en contrario). A él, y no a los superiores de las órdenes, era a quien correspondía librar las licencias para predicar y confesar, oficiar la misa y otras liturgias y paraliturgias, y velar por el adoctrinamiento de los fieles y la cabal administración de los sacramentos, exigiendo de todo ello cuenta a los curas. Como inútilmente se afanaba en repetir, los privilegios y exenciones de que gozaban los regulares les habían sido acordados temporalmente en los tiempos tempranos de la conquista espiritual; tiempos que en su opinión habían terminado.

En esta última apreciación, empero, residía buena parte de su error, pues si bien la difusión de la buena nueva evangélica entre los habitantes del Reino de Guatemala podía considerarse concluida (con toda la superficialidad que se desee), faltaba aún un largo trecho para que las órdenes dejasen de ocupar en la Iglesia local el papel primario que, de grado o por fuerza, tuvo que concederles el obispo Marroquín. ¿Cómo podría el mitrado sustituir la labor de los mendicantes, provisto de tan escasos clérigos, y cuyas conductas atrajeron a menudo severas reprimendas reales? ¿Cómo competir con el poderío económico de dominicos o franciscanos, provisto con las magras rentas del Obispado, dependientes en buena medida de los diezmos de un puñado de españoles, que apenas rebasaban el millar? ${ }^{6}$ Era demasiado temprano. De hecho, no sería sino hasta finales del siglo cuando, acompañando la expansión hispana hacia las ricas provincias orientales (el actual Salvador), el clero secular comenzara a hacer sentir su presencia en forma significativa y creciente, hasta llegar a administrar cerca del $30 \%$ del Obispado, en particular en las zonas donde se asentaba la población hispana, criolla y mestiza (Van Oss, op. cit.: 43, cuadro 1.5). Intentando, con poco acierto, fortalecer al clero regular (y, con ello, al propio poder episcopal), Villalpando ordenó entregar a los clérigos diversas doctrinas, como las que poseían los franciscanos en la rica área cacaotera de Suchitepéquez, ${ }^{7}$ aunque no logró sustituirlos en Totonicapán y Quetzaltenango. A justo título puede considerársele el iniciador del largo, complejo y espinoso asunto de la secularización, que habría de enfrentar a no pocos prelados guatemaltecos con el clero regular.

Atemorizados y enardecidos, dominicos y franciscanos enviaron una serie de alegatos y memoriales a la Corona, ${ }^{8}$ donde informaban sobre su propio proceder y el episcopal. Le acusaron de todo: de despojar a los frailes de sus doctrinas para -sin informar al rey como ordenaba el Real Patronato- ${ }^{9}$ poner en su lugar a clérigos genoveses y portugueses, desterrados de su tierra por conductas inapropiadas, que maltrataban

\footnotetext{
${ }^{6}$ Murdo Macleod calcula que entre 1565 y 1575 el número de españoles rondaba los 1 180: 500 en Santiago de Guatemala, 400 en Sonsonate, 150 en San Salvador y 130 en San Miguel (op. cit.: 183).

7 "Despojó violentamente a la Religión de los pueblos de San Juan Nagualapa, San Antonio Xuchitepéquez, San Francisco Zapotitlán, Mazatenango, Cuyotenango, Santiago Xambo, San Martín, San Felipe, San Luis y otros anexos, y de mano poderosa puso algunos clérigos que llevaba en su compañía, extranjeros y a quienes su ilustrísimo antecesor, por orden de su majestad, había desterrado del Obispado" (Vázquez, op. cit.: 185). Sobre la restitución en 1575 de Zamayaque y otros pueblos a los franciscanos, véanse las páginas 228 a 233 de la misma obra.

${ }^{8}$ De algún detalle de éstos, y de entre quiénes se levantaron (destacando varios caciques y principales indígenas), da cuenta Remesal (op. cit.: 488-489). Fray Francisco Vázquez (op. cit.: 185) apunta que se elevaron también quejas ante el sumo pontífice, aseveración que no encontramos en alguna otra fuente.

${ }^{9}$ Acusación registrada por Vázquez (op. cit.: 185), mas no por Remesal.
} 
a los indios; de "negociar" con éstos los curatos más pingües y de hacerse de la vista gorda frente a sus excesos a cambio de algún "arreglo"; de levantar informaciones falsas entre indios y españoles contra los frailes, ${ }^{10}$ a menudo "inducidos y aterrorizados de la parte del señor obispo", de descuidar la fábrica de la catedral, de extorsionar a los indios durante su visita pastoral (Vázquez, op. cit.: 185, 196-197) y hasta de mantener en su casa "ciertas mujeres que no son sus hermanas ni primas. Y que la una de ellas es de edad de 18 años, poco honesta, ${ }^{11}$ y por cuya intercesión, y de un sobrino suyo del dicho obispo, con dádivas y presentes, han de negociar con él los que han de conseguir algo" (Remesal, op. cit., II: 485-487).

A decir de los cronistas religiosos, la pequeña ciudad de Santiago estaba convulsionada. Los dominicos optaron por abandonarla, trasladándose al pueblo de San Martín, vecino a Chimaltenango, pero fueron detenidos por los atribulados vecinos (Remesal, ibid.), mientras que los franciscanos decidieron en junta provincial atender a una vieja solicitud del obispo de Chiapa, Tomás Casillas, y retirarse a Ciudad Real "hasta tanto viniera resulta de España y de Roma de todo lo que se había informado". Tras oír misa, los 34 frailes de la provincia consumieron las sagradas formas, entregaron las llaves de iglesia, sacristía y portería del convento al capitán Andrés Ortiz, y salieron en procesión desde la iglesia cantando el salmo In exitu Israel de Agypto, como si de un nuevo exilio bíblico se tratase. Con su típico estilo barroco, el cronista Vázquez narra el pesar que inundó a indios y españoles al ver a los frailes a punto de ausentarse, y refiere cómo hubo de intervenir el alguacil mayor, en nombre del gobernador Briceño, para convencerlos de dar marcha atrás. Buena parte de ellos permaneció hospedada en casa del alguacil por más de un año, "para obviar los pobres frailes los nuevos motivos que podía tomar el señor obispo para perseguirlos" (Vázquez, op. cit., I: 189-193).

No menos inestable era la situación en los pueblos de indios, que veían aproximarse la Cuaresma de 1568 desprovistos de frailes que les administrasen el obligado sacramento de la confesión u otros, o recibiéndolos de individuos no ordenados. ${ }^{12}$ Poblados hubo que se amotinaron, como Totonicapan, donde los comisarios enviados por el mitrado para requisar las llaves de la sacristía de manos de los franciscanos fueron corridos por los indios, y "lo hubieran pasado mal" de no ser por la intervención de los religiosos para calmar los ánimos. Y los de Quetzaltenango recibieron con una lluvia de piedras a los comisarios que mandó Villalpando para despojar a los franciscanos de su doctrina (Vázquez, op. cit., I: 187).

Finalmente, las órdenes lograron que Felipe II, en una severa (e injuriosa) cédula del 30 de agosto de 1567, desaprobase la actuación del prelado y pidiera al arzobispo de

\footnotetext{
${ }^{10}$ Preguntando "cosas que ellos jamás presumieron de nosotros, no debiéndolo hacer conforme a derecho, pues no es nuestro juez", se quejaría el 27 de noviembre de 1567 el provincial fray Tomás de Cárdenas ante el licenciado Briceño, por entonces gobernador de Guatemala (Remesal, ibid.).

"La real cédula fue en este sentido incluso más injuriosa (por suspicaz) de lo que registra Remesal, pues apuntaba "y que a la dicha moza la había casado [el obispo] con un criado suyo, y después tuvo forma de echar al marido de esa dicha ciudad, so color de que no se había podido casar con ella por ciertas causas que le opusieron, en mal ejemplo de los vecinos y naturales de esa tierra" (apud Vázquez, op. cit.: 197).

12 Vázquez llega incluso a asegurar que en poblados como Santa Catarina Ixtaguacán "hizo oficio de párroco, bautizó y casó Cristóbal de Morales, secular sin orden sacro, mayordomo de la iglesia, por comisión del bachiller Juan Alonso, tesorero de la iglesia catedral" (op. cit.: 186).
} 
México enviar a Guatemala un visitador para informarse puntualmente de los excesos que se imputaban al obispo y así proceder en consecuencia (Juarros, 1981: 151). ${ }^{13}$ Antes de un mes, el 27 de septiembre, se enviaba una nueva cédula real, dirigida a la Audiencia "que habemos tornado mandar a fundar en la ciudad de Santiago de la provincia de Guatemala", donde el monarca informaba haber obtenido del papa un breve dando "facultad para que los religiosos de las órdenes de santo Domingo, san Francisco y san Agustín [sic] administren en los pueblos de indios de esa tierra los sacramentos como lo solían hacer antes del Concilio Tridentino, con licencia de sus prelados, sin otra licencia". Deberían notificar de ello al obispo y velar por su cumplimiento (apud Remesal, op. cit.: 490).

El mencionado breve, que se fecha el 24 de marzo de 1567, bajo el pontificado de Pío V (dominico él mismo), tras señalar que lo hacía movido por la solicitud real, confirmaba los privilegios de los mendicantes de manera contundente:

[...] Por el tenor de las presentes les damos licencia a todos y cualesquier religiosos de cualesquiera órdenes, aun mendicantes, para que en las dichas partes de Las Indias y en los conventos de sus religiones -o los que viven fuera de ellos, con licencia de sus perladosen los lugares que por la tal licencia se les señalaron o se les hayan de señalar, libre y lícitamente puedan ejercitar el oficio de curas, celebrar matrimonios y administrar los eclesiásticos sacramentos como hasta ahora lo han acostumbrado hacer, con tal que guarden la forma del santo Concilio de Trento en todas las demás ceremonias y solemnidades como hasta ahora lo han hecho y acostumbrado. Y que juntamente puedan predicar la palabra de Dios y oír confesiones sin licencia de los ordinarios ni de otra cualquiera persona, con tal que los dichos religiosos sepan la lengua de los indios de la dicha provincia y tengan licencia de sus perlados, alcanzada, según se ha dicho, en los capítulos provinciales.

Y demás desto establecemos y ordenamos, por la misma autoridad y tenor de las presentes, que en los lugares de aquellas partes en donde hay conventos de religiosos que tienen cargo de almas, no se innove nada por parte de los dichos obispos.

$\mathrm{Y}$ así debe ser juzgado y definido por cualesquier jueces y comisarios, de cualquiera condición y calidad que sean, quitándoles a todos y a cualquiera dellos toda la licencia y autoridad de juzgar e interpretar. Y todo cuanto en contrario de esto se hiciere por cualquier persona o autoridad, científica o ignorantemente, lo declaramos por nulo y de ningún valor (apud Remesal, op. cit.: 491). ${ }^{14}$

Conseja harto difundida en su tiempo fue que, al ser notificado de la cédula real, a principios de agosto de $1569,{ }^{15}$ Villalpando exclamó: "De Dios y no del rey he recibido mi Iglesia, y a Él estoy pronto a dar cuenta de ella" (Juarros, op.cit.: 198). Cierto o no, al poco tiempo tendría ocasión de hacerlo, pues mientras realizaba una visita pastoral en la provincia de El Salvador, le sorprendió la muerte. Refiere el cronista Vázquez:

[... en el pueblo de Chalchuapa o el de Santa Ana, camino de la provincia de Cuscatlán, le cogió la muerte. Habiéndose acostado su ilustrísima, al parecer sin achaque -por ser más del alma que del cuerpo el que le aquejaba-, entrando por la mañana un paje a verle, por

\footnotetext{
${ }^{13}$ El texto completo de la cédula es reproducido por Vázquez (op. cit.: 196-197). 195).

14 No fue éste el único decreto papal al respecto; de otros de similar tono trata Vázquez (op. cit.: 194-

${ }^{15}$ La fecha es proporcionada por el cronista Vázquez (op. cit.: 194).
} 
extrañar el que no hubiese llamado en toda la noche, le halló muerto y yerto, medio sentado en la cama, caída la cabeza y metida entre las dos rodillas, como que hubiera ahogádose, según manifestaba lo salido de los ojos. Así acabó este señor obispo sin que fuese necesario juez pesquisidor de sus procederes, porque el Justo Juez quiso serlo de este su sacerdote, y castigarle en lo temporal (como cree la piedad) para no privarle de la vida eterna. Requiescat in pace (op. cit.: 197).

Eguiara y Eguren resume la actuación del prelado en un párrafo breve pero sustancioso:

Como se hubiese empeñado en revocar a los sacerdotes seculares las parroquias entregadas por su antecesor a los regulares, apoyado en los decretos del reciente Concilio Ecuménico de Tren[t]o, que vedaban la administración de las mismas a los religiosos [...] se hizo un tumulto, y se mandaron ante el rey muchas querellas en demanda contra él. Dicen que por esta causa le mandó Felipe II una carta muy severa, y que, así que la leyó en el pueblo llamado de Santa Ana, adonde se había recluido, manifestó que estaba preparado para dar cuenta a Dios de la Iglesia que le había encomendado, y allí murió el año de 1569 (op. cit.: 675).

Pese a rescatar lo esencial, Eguiara se equivoca en tres puntos: el prelado no estaba "recluido" en Santa Ana, sino visitando la provincia; no se enteró del contenido de la cédula allí sino en la ciudad de Santiago, y no murió en 1569. Enmendando la plana a varios autores que han fijado su deceso en ese año, Estrada, con base en las actas de Cabildo, demuestra que en diciembre de 1570 aún se hallaba con vida. ${ }^{16}$ En enero de 1571 los cabildantes se daban por enterados de su muerte en la región de Santa Ana, provincia de San Salvador. Dos meses más tarde se acordó destinar las dos capillas ubicadas tras el altar mayor de catedral para sepultar sus despojos y los de las dignidades catedralicias que fuesen falleciendo (op. cit.; I: 156-160).

La disputa entre las órdenes y los prelados, en cambio, no fue sepultada; continuaría durante muchos años y en casi los mismos términos, como bien lo muestra el enfrentamiento que se registró -por idénticos motivos de fondo y bajo muy similares argumentos- en 1719 entre los religiosos y el obispo Álvarez de Toledo. ${ }^{17} \mathrm{Y}$ que el fantasma de Villalpando aún rondaba para entonces, lo muestra a las claras el que, justo a esos 150 años de su muerte, Álvarez achacara a los mendicantes la responsabilidad de su muerte. ${ }^{18}$

\section{El sínodo y sus resoluciones}

Como si hubiese naufragado en el mar de alegatos que suscitó la actuación de Bernardino de Villalpando, poca tinta mereció a los cronistas religiosos de la época colonial y a los historiadores que les siguieron el hecho de que el obispo hubiese convocado el primer sínodo realizado en la diócesis guatemalteca.

En efecto, si bien los escasos autores que han mencionado su realización aluden a su importancia, ninguno de ellos va más allá debido a que no pudieron consultar el do-

\footnotetext{
${ }^{16}$ De hecho el propio Vázquez registra actividades del obispo en 1570, año en que, asegura, emprendió la visita a la provincia de El Salvador (op. cit.: 197).

17 Vid Memoria eclesial guatemalteca, tomo III.

${ }^{18}$ Véase lo que comenta al respecto el cronista Ximénez (1999, V: 57, 77).
} 
cumento, que se consideraba irremediablemente extraviado. Así, Eguiara y Eguren, basándose en la Historia de la Iglesia de Guatemala de Raymundo Leal, da cuenta de su celebración, pero apenas acota que si bien tanto Leal como González Dávila dan fe de que se llevó a cabo, ${ }^{19}$ no se sabe cuándo se realizó, y que el "autógrafo, perdido por la injuria de los tiempos, en ninguna parte se ha encontrado" (op. cit.; II: 675, 781); otro tanto asientan Juarros, al apuntar que de tal concilio, "único que se ha tenido en esta ciudad $[. .$.$] no se encuentra vestigio alguno" (op.cit.: 151) y Estrada, el cual señala que$ Villalpando "convocó a un Sínodo para enero de 1566, en el cual se analizaría y pondría en ejecución lo aprobado por el Concilio de Trento y que había sido ratificado por el Segundo Mexicano", y agrega: "lamentablemente se ignora el paradero de dichas actas" (op. cit.: 154).

Para fortuna nuestra, como era común en estos casos, algunas de las disposiciones tomadas por los participantes en el sínodo levantaron la suspicacia de las autoridades civiles, celosas del cumplimiento del Real Patronato que, con o sin razón, consideraron violentado por ciertos capítulos del encuentro, lo que motivó el envío al Consejo de Indias de una copia de lo dispuesto. ${ }^{20}$ Gracias a dicho traslado ${ }^{21}$ sabemos ahora que el sínodo tuvo lugar entre el 13 y el 15 de octubre de 1566,22 aunque es de suponer que su preparación e incluso ciertas deliberaciones se iniciaron desde antes, pues resulta cuesta arriba creer que en tan pocos días se acordasen asuntos de tanta gravedad e importancia para la joven Diócesis. ${ }^{23}$

De hecho, si hemos de guiarnos por lo que en 1604 mandó asentar en el Segundo Libro de Cabildo el obispo fray Juan Ramírez, el 31 de enero de 1564 el Cabildo Sede Vacante había esbozado unas "constituciones y ordenanzas" 24 que acaso hayan servido como marco de referencia para las que se promulgaron en tiempos de Villalpando, pues si tomamos en cuenta que el obispo había llegado cerca de un año antes, es difícil creer que conociera con la profundidad suficiente la compleja realidad del Obispado. Ciertamente las disposiciones dadas en 1564 buscan en su mayoría reglamentar la actuación de los miembros del Cabildo, aspecto que las constituciones de Villalpando casi no abordan, ${ }^{25}$ pero esto podría obedecer al hecho de que lo relativo al desempeño de los prebendados había sido legislado poco antes.

Sea como fuere, es casi seguro que en la elaboración de estas nuevas directrices participaron activamente los miembros del Cabildo Eclesiástico, integrado por entonces -a juzgar por un acta de Cabildo del 9 de mayo de 1566- por el arcediano Francisco Peral-

${ }^{19}$ Éste se limita a señalar "celebró Sínodo" (op.cit.: 153).

${ }^{20}$ Dicha copia fue localizada por Claudia Margarita Báez en el Archivo General de Indias, en el curso de una pesquisa tendiente a acopiar datos para los estudios introductorios de la serie de Visitas Pastorales de Guatemala que edita el Centro de Estudios Mayas.

${ }^{21} \mathrm{AGI}$, Patronato 182, R. 24. "Oposición a varios artículos del sínodo de Guatemala. Expediente promovido por Diego Ramírez, fiscal de la Audiencia de Guatemala, oponiéndose a varios artículos del sínodo celebrado los días 12 y 13 de octubre de 1566 por el obispo Bernardino de Villalpando".

${ }^{22}$ No en enero, como señala Estrada (op. cit.: 154).

${ }^{23}$ A manera de comparación señalemos que el Sínodo del obispado de Yucatán efectuado en 1721 ocupó del 6 de agosto al $1^{\circ}$ de octubre (Eguiara y Eguren, op. cit., II: 782-783).

${ }^{24}$ Apud Ruz, De Paz y Vicencio, op. cit.

${ }^{25}$ Pero que ocupan, en cambio, buena parte de la legislación dada por Marroquín, que fue al parecer la que los cabildantes intentaron actualizar y completar. 
ta, el chantre Pedro de Liébana, el tesorero Martín de Dios y fungiendo como canónigos Cristóbal de Cepeda y el licenciado Ramírez, ${ }^{26}$ pero desconocemos quiénes más estuvieron presentes; acaso algunos de los clérigos que aparecen firmando la "publicación" de las mismas. ${ }^{27}$

Con independencia de quienes hayan sido sus autores, de lo que no cabe duda es de la importancia del documento, que aúna a su carácter original el hecho de haber intentado adecuar la realidad local a las disposiciones tridentinas a escaso un año de haberse dado a conocer las disposiciones del Concilio, permitiéndonos de paso aproximarnos a la percepción que sobre el estado de la Diócesis guardaba el grupo eclesiástico de mayor jerarquía de la misma, responsable directo de su conducción.

No se trataba, ciertamente, del primer conjunto de disposiciones que buscaban normar la conducción del Obispado, ya Marroquín había decretado algunas al tomar posesión de la sede guatemalteca en octubre de 1537 , pero amén de que éste se guió por la temprana legislación eclesiástica surgida en la Nueva España en las conocidas juntas efectuadas en México a partir de 1524, que tenían como objetivo primordial organizar la evangelización, no se trató de constituciones en el sentido pleno del término (y mucho menos sinodales, pues surgieron exclusivamente del mitrado), sino de una serie de normas que acompañaron la erección e institución de la sede. ${ }^{28}$ Aunque incluso Villalpando se refiere a ellas como "sinodales" en tres de sus constituciones $(28,32$ y 50$)$ y en su respuesta al fiscal.

En sus normas, Francisco Marroquín se entretuvo en instituir los cargos catedralicios (deanato, arcedianato, cantoría, maestrescolía, tesorería, 10 canonjías y prebendas, racioneros, medio-racioneros, capellanes, mayordomo o procurador y perrero), detallar sus funciones y señalar sus emolumentos; estipular lo relativo a las rentas episcopales (incluso lo concerniente a diezmos y primicias), instituir algunas misas obligatorias, normar las reuniones del Cabildo, erigir la parroquia de Santiago en catedral y regular los trajes y tamaño de la tonsura que deberían portar los clérigos. Prácticamente nada hay en ellas, en cambio, sobre los derroteros que debería seguir la evangelización o las peculiaridades de la administración de sacramentos; mucho menos menciones específicas acerca de la conducta de los eclesiásticos; puntos todos ellos, como veremos, centrales en las disposiciones de Villalpando.

Comparadas con las contenidas en otros escritos del mismo tenor surgidos en las diócesis que tenían jurisdicción sobre lo que hoy se considera como el área maya, las resoluciones adoptadas en este Sínodo son ciertamente magras (por decir lo menos) tanto en extensión como en profundidad. Baste recordar, entre los más famosos, el texto de las Constituciones diocesanas del Obispado de Chiapa, de Francisco Núñez de la Vega, editado en $1702,{ }^{29}$ o las Constituciones Sinodales, conforme al orden de los libros, títulos y santos decretos del III Concilio Mexicano, dispuestas para el obispado de Yucatán por el Prela-

\footnotetext{
${ }^{26}$ Primer Libro de Cabildos, f. 102 (apud Ruz, De Paz y Vicencio, op. cit.).

${ }^{27}$ Tales nombres constan al final del texto (vid infra).

${ }^{28}$ También Gálvez (1963: XIII) las califica como "Constituciones", y apunta que "le fueron entregadas al señor obispo Marroquín en la ciudad de México en 20 de octubre de 1537", despojándolo así, erróneamente, de su autoría.

${ }^{29}$ Aunque las más famosas, no fueron éstas las primeras constituciones otorgadas para el obispado de Chiapa y Soconusco, cuyos cuerpos legislativos son curiosamente más numerosos que los emitidos para la diócesis de Guatemala (véase al respecto Núñez de la Vega, 1988: 93-97).
} 
do de la misma, el Ilmo. Sr. Dr. D. Juan Gómez de Parada, del Real Consejo, en el Sínodo inaugurado en su iglesia catedral del día 6 de agosto del año de 1722, y clausurado el 2 de octubre del mismo año, que permanece inédito. ${ }^{30}$

Las diferencias son notables: el texto de Núñez, surgido exclusivamente de su pluma (pues se trata de unas constituciones diocesanas y no sinodales), explica a sus feligreses, a lo largo de sus más de 500 páginas de apretada escritura, los principios básicos de la doctrina cristiana (verdades de la fe, oraciones, mandamientos mosaicos y de la Iglesia, sacramentos, virtudes, pecados, obras de misericordia, frutos del Espíritu Santo y otros varios temas), ceremonias religiosas y bulas pontificias, seguidos por nueve extensas cartas pastorales que buscan, con metáforas, exhortar a sus ovejas para obtener la gracia y perseverar en ella y una serie de reales cédulas y autos episcopales. Todo ello, provisto de apostillas eruditas y numerosas citas bibliográficas. El objetivo del mitrado es claro: "buscaba reformar, nutriéndola en fuentes teológicas, la endeble cristiandad de su feligresía, a la vez que regular el manejo eclesiástico de la provincia de Las Chiapas y la gobernación de Soconusco $[\ldots]$ para remediar lo que intuye como los principales problemas de su Diócesis, intenta proveer a sus feligreses de una sólida base cristiana sobre la cual moldear la existencia diaria" (Núñez, op. cit.: 15-16).

Por su parte las Constituciones elaboradas en Yucatán bajo la dirección de Juan Gómez de Parada (éstas sí, sinodales), surgieron por encargo expreso de la Corona, la cual pidió al obispo que después de visitar la Diócesis llevase a cabo un Sínodo, "para formar estatutos que normaran el régimen espiritual y corrigieran los abusos detectados" (Solís, 2003: 202). Los participantes en él

... no omitieron nada referente a la disciplina eclesiástica, a la reforma de las costumbres y a la educación cristiana, guiándo[se] por la experiencia que había adquirido en la visita pastoral de las provincias, y al mismo tiempo llenas de todo género de erudición, sobre todo en teología, derecho, doctrinas conciliares, historia de la Iglesia y disciplina, de suerte que ese sínodo que redactó sea muy docto y digno de los antiguos Padres de la Iglesia... (Eguiara y Eguren, op. cit., 782-783).

Además de lo señalado en la cita anterior, cabe recordar que en sus más de 320 páginas las constituciones yucatecas dan fe del profundo interés del obispo no sólo en subsanar la que consideraba una deficiente evangelización de sus fieles mayas, sino también por "denunciar y tratar de aminorar la dura y evidente opresión que éstos padecían a manos de los diversos grupos de poder españoles, incluyendo a los representantes de la Iglesia"; de allí que, con el fin de motivar "un cambio en la mentalidad de los religiosos más acorde a las necesidades de la evangelización", se incluyeran instrucciones para los curas de indios (Solís y Peniche, 1996: xliii), lo que permite a Solís asegurar que, "en buena medida las Constituciones, tal como se escribieron, tenían la intención de avanzar en la verdadera reducción de los indios, impulsando la evangelización bajo reglas más precisas y por medio de religiosos más instruidos" (op. cit.: 206).

Por otra parte, como puede observarse, las dos extensas obras anteriores surgieron del conocimiento de primera mano que ambos mitrados tenían de sus diócesis tras va-

\footnotetext{
${ }^{30}$ Gabriela Solís Robleda prepara actualmente su edición en la serie Fuentes para el estudio de la cultura maya, del Centro de Estudios Mayas de la unam.
} 
rios años de residir en ellas (ocho para Núñez, ${ }^{31}$ seis en el caso de Gómez) y haberlas recorrido, y hacen expreso -cada una a su modo- el compromiso de los prelados con su feligresía, no sólo en lo que a su religiosidad propiamente dicha corresponde, sino incluso en aspectos varios de su cotidianidad que, para un ojo poco avezado, parecerían trascender la esfera sobre la cual debían de velar los pastores, mientras que las surgidas bajo las directrices de Villalpando, como ya señalamos, se fechan a los dos años de su toma de posesión y, según todo parece indicar, antes de haber emprendido visita alguna a su Diócesis, lo cual explicaría las escasas alusiones que -a diferencia de Núñez y Gómez- hace a cuestiones específicas.

Pero, ¿de qué tratan las constituciones guatemaltecas? ¿Son tan irrelevantes como para justificar el silencio a que les condenaron sus contemporáneos e incluso los prelados que sucedieron en la mitra a Villalpando? Veámoslas con algún detenimiento, abordándolas por temas más que en el orden de presentación, a fin de facilitar una visión armoniosa de su contenido.

Tras un breve proemio, cuyo objetivo primordial es legitimar, a vuelapluma, la celebración del sínodo y las directrices que de él se desprendieron (incluyendo algunas consideraciones de historia sacra) el texto inicia señalando la obligación de cumplir con lo que más adelante estipula, apoyándose en el sínodo previamente realizado en México (1565), por entonces sede metropolitana de la diócesis de Guatemala. ${ }^{32}$ Viene a continuación el exhorto para cumplir con lo decretado por el Concilio de Trento y las disposiciones tomadas a fin de velar por dicho cumplimiento (a través de nombrar seis "examinadores", destacando algunos miembros del Cabildo), para lo cual se darían a conocer partes del mismo en las iglesias locales (Constitución $1^{\mathrm{a}}$ ), seguida por otra orden para respetar lo acordado en el Segundo Concilio Provincial Mexicano $\left(2^{\mathrm{a}}\right)$.

Punto de interés primario, contenido en la $3^{\mathrm{a}}$ constitución, es el relativo a la administración gratuita de los sacramentos, ya que según se señala no era inusual que ciertos eclesiásticos solicitasen de los indígenas algún tipo de retribución a cambio, por lo general en forma de cacao, mantas e incluso dinero, en ocasiones instruyendo a los alguaciles de los pueblos para que motivasen a los naturales a hacerlo. Villalpando, a fin de desarraigar este abuso, amenazó con una multa de 50 pesos de oro a quienes transgrediesen por primera vez y con destierro perpetuo del Obispado a los reincidentes. Que la disposición no tuvo mayores efectos se comprueba al revisar documentación posterior, la cual muestra las continuas denuncias de sus sucesores en este sentido al menos hasta el siglo xviII, época en que, a decir de algunos, no pocos indios habían llegado a creer que la salvación podía ser objeto de compraventa.

Empero, la constitución siguiente aclara que bien podía aceptarse -e incluso estimularse- la entrega de ofrendas y donativos, siempre y cuando fuesen voluntarios, ya que resultaban de importancia para el sustento de los eclesiásticos. De paso se califica como "mala doctrina" (punible con excomunión mayor) la que esparcían algunos españoles ("por mala voluntad que tienen a nuestros ministros o por otros respetos") incitando

${ }^{31}$ La última carta pastoral incluida en el texto se fecha en 1698, a 14 años de haber tomado Núñez posesión del Obispado, pero aquí nos referimos al cuerpo central de las Constituciones propiamente dichas.

${ }^{32}$ Cabe recordar que ésta no sería elevada al rango de Arzobispado sino hasta el 16 de diciembre de 1743, por bula de Benedicto XIV. 
a los naturales a no obsequiar a sus evangelizadores, pero al parecer para ese entonces los indígenas tampoco requerían mayor incitación, pues se les califica como "naturalmente descuidados en las cosas de nuestra santa fe católica" y se alude a que "las ofrendas no son como solían". Para obviar este inconveniente se ordena, pena de excomunión mayor, que nadie se atreviese a aconsejar en tal sentido a los indios. Asimismo, se solicita a los feligreses denunciar los excesos de los ministros en la obtención de tales ofrendas.

La constitución $5^{\text {a }}$ también aborda el tema de la administración de los sacramentos, pero aludiendo ahora a la obligatoriedad de confesar al menos una vez al año. Para asegurarse del cumplimiento del precepto, los curas deberían levantar padrones y verificar que sus feligreses, de cualquier calidad que fueran, lo satisficiesen. Los regulares que contaran con licencia para confesar deberían entregar la cédula respectiva a los fieles que solicitaran tal servicio, y los curas a su vez enviarían al obispo la información final $\left(5^{\mathrm{a}}\right)$; por su parte, los dueños de estancias y haciendas habrían de declarar con detalle los nombres de los criados españoles, mestizos, mulatos, negros, indios e indias a su servicio, a fin de que pudiesen incluirse en el padrón. Patrones y sirvientes serían excomulgados en caso de faltar a esta obligación $\left(6^{\mathrm{a}}\right)$. Previendo el que por "algunas ocupaciones justas" hubiese feligrés que no pudiera confesarse en el período de Cuaresma, se prorrogaba el tiempo para hacerlo hasta el tercer domingo después de Pascua de Resurrección. Después de éste, el español, mestizo, mulato o negro que no hubiera cumplido, sufriría excomunión y una multa de cinco pesos $\left(7^{\mathrm{a}}\right)$. Nada se menciona en cambio sobre los indios que no cumpliesen con el precepto.

Dato de particular interés es el contenido en la $8^{\text {a }}$ constitución, que -pena de 50 pesos y privación del beneficio a los curas reincidentes-, prohíbe la costumbre estipulada en tiempos previos de confesar "por intérprete" dado el desconocimiento que se tenía de las lenguas locales. Esta situación, según se aclara, había variado, pero no, como era de esperar, porque los eclesiásticos fueren para entonces avezados en los idiomas mayances (predominantes en la Diócesis), sino por el hecho de que "casi todos o la mayor parte de los ministros del santo evangelio saben la lengua mexicana, común en este Obispado". Medio siglo después el obispo Juan de las Cabezas Altamirano apuntaría, en su informe de visita de 1613 , que mal podían descargarse la conciencia real y la del prelado creyendo que bastaba manejar dicho idioma para adoctrinar a los indios de Guatemala, pues "su uso se hallaba restringido a los principales indígenas 'y gente de repartimiento', en tanto que quienes no salían de sus pueblos (mujeres, pobres e impedidos) eran monolingües en sus lenguas maternas. De allí que asegurase que no bastaba a los curas su conocimiento para descargar la real conciencia en lo que a cristianización to-caba, si no que debían aprender las otras, como hacían los mendicantes." ${ }^{33}$

Es de resaltar que en este punto las constituciones sinodales aluden tanto a regulares como a seculares, lo que parecería cuestionar la continua aseveración de los mendicantes de que sus miembros, a diferencia de los seculares, manejaban "con suficiencia" los idiomas maternos de los indios. Se puntualiza, asimismo, que los clérigos recién llegados de España deberian ser auxiliados en la administración de este sacramento por

${ }^{33}$ Mayor información al respecto en Ruz et al., Memoria eclesial guatemalteca, I: 534. 
otros clérigos, en tanto aprendían los idiomas nativos. Encargo similar se hace a los regulares en la constitución $10^{\mathrm{a}}$, para que auxiliasen a otros ministros en caso necesario, "pues es obra meritoria y de caridad, y de las obras que ellos suelen y acostumbran hacer." Por su parte, la constitución $9^{\mathrm{a}}$ se detiene en el caso de los vagamundos e indios tratantes, quienes, por andar de un pueblo en otro, buscaban excusarse de cumplir con este precepto alegando haberse ya confesado en algún otro pueblo. Para obviar el incumplimiento se autorizaba al cura del pueblo donde se hallasen a interrogarlos acerca de la doctrina y confesarlos, independientemente de que fuesen o no sus feligreses. De negarse a cumplir, deberían ser remitidos al diocesano.

Pese a lo aseverado en la constitución $8^{\mathrm{a}}$ acerca del empleo común de la lengua mexicana en el Obispado, la número 11 alienta a los ministros a aprender los idiomas locales, "con el mayor cuidado y diligencia que pudieren, so pena que serán castigados a nuestro arbitrio", mientras que la $12^{\mathrm{a}}$ alude al adoctrinamiento básico de los fieles, que abarcaría el memorizar "las cuatro oraciones de la santa madre Iglesia" (es de suponer Padre Nuestro, Ave María, Salve y Credo), los artículos de la fe, los mandamientos de Dios (los llamados mosaicos) y de la Iglesia, los sacramentos y los pecados tenidos por mortales. Tal acción se llevaría a cabo los domingos y fiestas de guardar para el conjunto de los fieles, y diariamente para los niñas y niños pequeños, auxiliándose con algunos indios poseedores de tales conocimientos, que se antojan asaz rudimentarios. Otra forma de auxiliarse en esta tarea sería el recurrir a un manual redactado por los dominicos -con preguntas y respuestas "muy buenas y santas"-; especie de doctrina elemental sobre cuyas características nada más se informa, pero que es de suponer existía en diversas lenguas.

Se menciona asimismo ser costumbre que en algunas partes los indios cantasen las Horas canónicas y las denominadas "Horas de Nuestra Señora", actividad piadosa que el Sínodo consideró de poco provecho ya que se entonaban en latín. A cambio de ello ordenó cantasen "en su lengua las cuatro oraciones y lo demás aquí contenido", sin duda aprovechando el antecedente y, sobre todo, la afición que desde un inicio mostraron los naturales a este tipo de paraliturgias acompañadas de música y cantos, que engarzaban con facilidad en la tradición ritual prehispánica.

La constitución siguiente $\left(l a 3^{\text {a }}\right)$ insiste sobre el adoctrinamiento, pero esta vez específicamente el de españoles y mestizos, frente a los cuales se muestra más rigor: debería negárseles la absolución si ignoraban aspectos tan elementales de la fe como las cuatro oraciones básicas, los mandamientos y los artículos de fe, o fuesen incapaces de enumerar los sacramentos. Mucho más adelante, casi al final del documento, se regresaría sobre el tema del adoctrinamiento de los fieles que no viviesen en las repúblicas de indios, pues la constitución número 49 , tras recordar que se había proveído que todos los domingos y fiestas de guardar se enseñaría la doctrina "a los negros y a todo servicio", mandaba a los patrones enviar a sus sirvientes para que fuesen instruidos.

Particularmente polémico se antoja lo ordenado por la constitución 16, relativa al sacramento de la eucaristía, donde se prohíbe -salvo autorización expresa del obispo, provisor y "visitadores"- administrarla a indios, negros y mulatos, ya que, como "tiernos en la fe", arriesgaban acercarse faltos de "limpieza de conciencia" al sacramento y, por ende, recibir a cambio no salud espiritual sino condenación. Cabe recordar que este punto, que invoca en su apoyo una resolución tridentina, había provocado grandes 
enfrentamientos entre los eclesiásticos de todo el virreinato de la Nueva España en la primera mitad del siglo xvı, y pese a que la bula Altitudo divini consilii había resuelto a favor de la administración de la eucaristía a los indios, la polémica seguiría viva al menos hasta 1573, enfrentando incluso a los miembros de una misma Orden (Ricard, 1933: 148-153). No deja de ser curioso advertir que la disposición no incluía a los mestizos, que si bien podían tacharse de descendientes de "cristiano viejo" al menos por alguna de sus líneas de filiación, sabemos crecían a menudo bajo los cuidados de una madre india, lo que difícilmente aseguraba un adoctrinamiento profundo. $Y$ eso sin tener en cuenta que, como hace claro la constitución 13, españoles había que ignoraban incluso aspectos elementales de la doctrina.

Mucho más generosos se mostraron los integrantes del Sínodo cuando se trató del sacramento de la extremaunción, ordenando a curas, vicarios y religiosos que lo ofrecieran, tras la confesión, a los indios que estuvieran en artículo de muerte, "declarándoles la gracia que por él se recibe, y viendo señales por donde le merezca recibir". Esta resolución habría incluso de destacarse durante los sermones, a fin de que los indígenas la conociesen y mantuvieran sus casas limpias en caso de que se les llevase el viático $\left(18^{\mathrm{a}}\right)$.

Lo concerniente al sacramento del matrimonio ocupa cuatro constituciones: de la 20 a la 23. La primera alude al tiempo que transcurría entre los desposorios y la bendición nupcial; lapso que en ocasiones se prolongaba hasta por tres y cuatro años (por motivos que no se señalan, aunque acaso no fueren ajenos a ellos factores económicos) y que el Sínodo buscó acortar a un máximo de un mes, pena de excomunión y 10 pesos de oro de minas a los contrayentes españoles, mestizos, negros y mulatos. Para el caso de los naturales, la bendición debería hacerse inmediatamente después de los desposorios. La constitución 21 aborda un paso previo: el de las amonestaciones. De acuerdo con Trento, éstas debían hacerse "tres veces en tres fiestas", pero tomando en cuenta que a menudo transcurría buen tiempo entre una y otra visita de los curas a los pueblos, y que esto provocaba que los indios desistiesen o, pero aún, consumasen la unión física antes de ser desposados, se autorizaba correr las tres amonestaciones en un solo día o fiesta $y$, de no haber impedimento, casarlos de inmediato, todo ello siempre y cuando el cura sólo permaneciese un día en el lugar, pues si estuviese al menos tres, lo haría a lo largo de éstos. La siguiente (22) remite al asunto de las arras, apuntando que si bien era costumbre en la Iglesia entregasen los contrayentes 13 monedas, dada la pobreza de los naturales y la disparidad en el valor de las ofrendadas, y buscando evitar fueren compelidos a entregar más de lo que pudiesen o deseasen, a partir de este momento "los tales naturales y todos los que recibieren las bendiciones de nuestra santa madre Iglesia lleven tres monedas y éstas, las que ellos quisieren". El cura que violase tal disposición sería severamente multado y castigado. Pero también (en la Constitución 23) se contemplaban sanciones para los propios indígenas, en especial a aquellos que, siguiendo antiguas costumbres, obligaban a sus hijas y parientas a contraer matrimonio con quien no fuera de su agrado ("que entre ellos se llama vender las mujeres"), lo que se traducía en desavenencias conyugales. Para evitarlo, el cura debería averiguar si los contrayentes actuaban por propia voluntad o habían sido compelidos en algún modo.

Casi al finalizar las constituciones vuelven sobre el tema del matrimonio. La número 44 alude a aquellos casados que, por estar lejos de ellas, no hacían "vida maridable" 
con sus mujeres, pese a las diversas disposiciones reales que les obligaban a ello. Buscando pues, el mejor servicio de ambas majestades, se ordena a clérigos y religiosos no absolver a los penitentes que confesasen una ausencia de sus mujeres mayor de dos años, y remitirlos al obispo. No terminan allí, empero las disposiciones relativas a los casamientos; en una nota agregada al final del texto ocho días después de concluido el sínodo, se agrega una orden a los curas para que, de acuerdo con lo decretado en Trento (sesión 2, cuarto capítulo), tengan en sus iglesias libros donde "con día, mes y año asienten los que casaren". De no cumplir con ello, serían multados con " 50 pesos por la primera vez, aplicados por tres partes, la tercia para la Cámara de su señoría y la tercia para el juez que lo sentenciare y la tercia para el acusador, y por la segunda vez la pena de 100 pesos, aplicados según dichas y, por la tercera, privación de beneficio".

Curiosamente lo concerniente al sacramento del bautismo no figura sino hasta la Constitución 25, que tras aludir a las faltas por exceso o insuficiencia, estipula lo que deberán llevar los fieles cuando pretendan bautizar a sus hijos: una vela de cualquier tipo, el capillo ${ }^{34}$ y "la limosna que quisieren o pudieren para el sacerdote". Cualquier exceso por parte de curas o vicarios (quienes, se deja entender, acostumbraban exigir más a los feligreses) sería gravemente castigado.

A partir de la constitución 14 , aunque no de manera continua, comienzan a figurar disposiciones relativas a los eclesiásticos y su desempeño. Así, dicha constitución estipula que habían de rezar (o en su caso cantar) los oficios divinos siguiendo lo acostumbrado en la diócesis de Sevilla, tal y como se había acordado desde la erección del Obispado (y el arzobispado de México, su metropolitano).

La constitución 15, buscando salvaguardar las preeminencias episcopales y en particular las catedralicias, recordaba a los eclesiásticos la obligación de tener licencia del diocesano para poder administrar los sacramentos, y la prohibición de hacerlo fuera de la catedral ("en sus casas ni monasterios") en el caso de los residentes en la ciudad de Santiago. Vinculadas con ésta se hallan la número 17, que, pena de 50 pesos, proscribe la celebración de misas "en casa particular ni en parte alguna que no sea iglesia y lugar decente y determinado para tan alto sacramento", 35 y la 19 , que, con el pretexto de alentar la participación de los fieles en la misa que mensualmente se oficiaba en catedral por cuenta de la Cofradía del Santísimo Sacramento, prohíbe a los regulares pronunciar sermones en tales fechas en sus conventos, e incluso les ruega que, de coincidir sus festejos con los catedralicios, cambien la fecha. Que los feligreses preferían asistir a las liturgias celebradas por los mendicantes lo declara sin pudor el propio Sínodo: "la gente es poca y habiendo fiesta en otra parte no viene ninguna".

Por su parte la Constitución 24, a fin de normar de manera más efectiva la administración religiosa (en particular en lo relativo a los sacramentos y sobre todo al matrimonio), ordena cesar en el abuso existente de que tanto clérigos como regulares se

\footnotetext{
34 Capillo: cubierta de lienzo blanco, a manera de muceta, empleada para cubrir a un niño durante su bautismo (Diccionario de Autoridades, 1990, II: 145). Cabe recordar que en el obispado de Guatemala, cuando los padres no podían proveer al niño con la prenda, se estiló que empleasen durante la ceremonia el capillo perteneciente a la iglesia, pagando una cuota por ello (véase Ruz et al., 2004).

${ }^{35}$ Resulta por cierto curioso el que un sínodo compuesto por dignatarios eclesiásticos califique una misa como un sacramento.
} 
entrometiesen en jurisdicciones que no les correspondían y confiriesen tales sacramentos sin autorización del cura responsable. Si bien se señala que cualquier trasgresor sería "gravemente" castigado (sin especificar la manera), la constitución se detiene en especial en los regulares, apuntando: "encargamos y rogamos a los religiosos así lo guarden y cumplan, con apercibimiento que desde ahora para entonces luego que cualquiera de ellos traspasare esta nuestra sinodal, por el propio hecho es nuestra voluntad se le quite y quitamos nuestro beneplácito y voluntad que para administrar los santísimos sacramentos tiene, demás que encargamos a sus prelados al trasgresor de esta nuestra sinodal, demás de lo dicho, lo castiguen." De alguna manera abunda en ello la número 46 , que prohíbe a los curas permitir oficiar misa a quien siendo regular no portase autorización de su superior o licencia del obispo o su provisor, o de cualquiera de estos dos últimos en caso de tratarse de un clérigo secular.

A partir de la constitución 27 y hasta la 42 (casi un tercio del total), los sinodales se abocan a regular actitudes y actividades de quienes se desempeñaban como pastores de almas, incidiendo en muy diversos aspectos de lo que se esperaba de ellos, en especial en el trato cotidiano con sus ovejas. Comienzan justamente por el inicio: recordando las edades que establecía el Concilio Tridentino para poder ser admitido al subdiaconado, diaconado y presbiterado (22, 23 y 25 años respectivamente) y los otros requisitos: presentar "probanza de su vida y costumbres y linaje". En el caso de los clérigos, que a diferencia de los religiosos no contaban con el respaldo económico de la Orden, se aunaba a lo anterior la obligación de presentar, bien 500 pesos de patrimonio, bien la titularidad de un beneficio que asegurase su solvencia económica, sin duda buscando disminuir las posibilidades de una conducta ambiciosa que gravitara sobre la economía de los feligreses.

Vienen luego disposiciones sobre la conducta honesta y decente que debería caracterizar a los clérigos en su hablar, comer, beber y vestir, ya que se tenía al buen ejemplo como el modo más efectivo de predicación; en particular entre los indios, tiernos en la fe. Por ello debería evitarse la ostentación de lujos innecesarios. A diáconos y subdiáconos quedaría por ejemplo proscrito llevar terciopelos, becas y rasos en sus manteos, mientras que a los sacerdotes se prohibía el empleo de calzas acuchilladas con rasos, terciopelos negros o de colores no adecuados al estado sacerdotal; mucho menos deberían "andar en cuerpo", ${ }^{36}$ sino siempre portando ropas largas y de colores apropiados. Incluso se les restringe emplear el caballo con fines mundanos. Las penas se antojan severas: a más de perder la ropa, pagarían 10 pesos de multa la primera vez y 20 la segunda. Una nueva reincidencia significaría la pérdida del beneficio donde se desempeñaban como curas ( 28 y 29). Asimismo, se buscó legislar el contacto corporal con los fieles, poniendo mayores restricciones al que se daba con mujeres (42).

Se intentó regular también el hospedaje que los curas podrían ofrecer en sus casas a los comerciantes españoles que pasasen por el pueblo, alegando que "de la mucha conversación que con ellos tienen, causa menosprecio y venir a ser tenidos en poco y menospreciados", amén de que descuidaban la administración de los sacramentos, entretenidos en la charla (30). En vez de ello se les exhortaba al estudio, fijándoles inclu-

\footnotetext{
36 "Modo adverbial que explica el modo de estar uno vestido con la vestidura precisa que ciñe el cuerpo: esto es, sin capa, manto u otras ropas de mayor adorno" (Diccionario de Autoridades, op. cit., II: 690).
} 
so un mínimo: deberían comprar y tener consigo "a lo menos... la Biblia y algún sermonario y el Manual de Navarro o la Suma Gayetana [sic] o Silvestrina" (31).

Pero, a juzgar por algunas de las constituciones siguientes, no era sólo lo continuo y dilatado de las charlas con los comerciantes hospedados en la casa parroquial lo que preocupaba al obispo y sus cabildantes; algo recelarían de la naturaleza de las mismas, cuando observamos que de la constitución 32 a la 36 se alude a las actividades mercantiles que llevaban a cabo algunos curas, aprovechando la autorización dada por Marroquín para comprar hasta 12 cargas de cacao; autorización que se canceló, señalando severas penas a los trasgresores, que iban hasta el destierro del Obispado. ${ }^{37}$ Únicamente se les permitiría vender, y "sin escándalo", lo que les ofrendasen los indígenas en ropa, cacao y otros frutos de la tierra, a fin de comprar otros productos de que tuviesen necesidad. Una constitución específica (la 34) establecía la estricta prohibición de vender aguardiente a los indios o el darlo "por vía de intereses", mientras que la siguiente ordenaba retirar de las actividades comerciales a los negros y negras que algunos clérigos mantenían ocupados en granjerías en los pueblos de indios y villas españolas (en especial en la de La Trinidad), y otro tanto se prohibió a aquellos que alquilaban a los negros de su propiedad para desempeñar trabajos ajenos.

Otros eclesiásticos se insertaban en la esfera mercantil de manera asaz peculiar: "compraban" las deudas que los indios mantenían con los españoles -derivadas en particular de ventas a crédito-, encargándose más tarde de cobrarlas, causando "molestia y agravio" a los naturales a quienes, a diferencia de los mercaderes, tenían siempre al alcance. $Y$ puede suponerse que cobraban con intereses, ya que la constitución 36 asienta que "por efecto de estos trueques y tratos resulta comprar nuestros clérigos para ganar, [lo] que por Derecho les está prohibido".

Las constituciones siguientes aluden tanto a regulares como a seculares, ya que atañen a servicios y colaboraciones prestadas por los indios, bien con el fin de mantener en buen estado el templo y la casa cural (37), bien en su desempeño como cargadores o tamemes (38). Para obtener el apoyo de los feligreses indios en lo primero deberían consultar antes con el prelado, mientras que para lo segundo habrían de regirse por las disposiciones reales, limitándose a transportar lo indispensable para cumplir con sus deberes religiosos y gozar de mínimas comodidades al visitar los pueblos, evitando cargar a los indios "con ninguna ropa ni otra cosa". Esta última disposición, que pudiera parecer extraña, apunta a la costumbre que tenían los eclesiásticos de exigir a los pueblos donde doctrinaban el que les entregasen indios cargadores (los llamados tayacanes o indios "de cincho"), a los cuales hacían transportar, a través de largas distancias y por lo común sin pago alguno, efectos personales, conventuales y hasta otros destinados al mercado. Basta revisar las denuncias hechas por los indios del Obispado en 1720 , durante una visita pastoral, ${ }^{38}$ para darse cuenta de que las disposiciones de este sínodo no lograron eliminar el abuso.

\footnotetext{
37 El texto menciona una "sinodal" de Marroquín, pero ignoramos a qué se refiere. En las disposiciones dadas por dicho obispo en 1537 no consta alguna que aluda siquiera a esta autorización a los clérigos para realizar actividades mercantiles; al menos no en las rescatadas por el cronista Remesal, ni en la edición que las traduce al español (1966: 319-342), ni en su versión original latina (1988: 193-208).

${ }^{38}$ Buena parte de ellas se registraron en El Salvador, y contra los dominicos (vid Ruz et al., 2004).
} 
Violencia sin duda mayor era aquella a la que alude la constitución 39 , que prohíbe a los eclesiásticos azotar o mandar azotar a los indios por no aprender la doctrina cristiana. Se permitiría, sí, algún tipo de castigo -"conforme a la calidad del delito"- contra los naturales que usasen de o incurriesen en "blasfemias, amancebamientos, hechicerías y supersticiones," así como "algún castigo moderado" para el bautizado renuente a aprender la doctrina (que se suponía debía ya de conocer), "pues si en todo se hubiese de dejar a la voluntad de los dichos naturales, entendemos aprovecharían muy poco en las cosas de nuestra santa fe católica", pero sancionar otras faltas se reservaba al ordinario.

El apartado que sigue, el número 40 , abunda sobre el punto al ordenar a curas y vicarios que pongan "especial cuidado" en velar por la asistencia de los indígenas a la misa, autorizando el que, en caso de faltar sin causa justificada, "públicamente en la fiesta que se siguiere, delante de todo el pueblo, le reprendan de palabra. Y permitimos que el tal cura le pueda penar en una penilla moderada según y como se hace en los reinos de Granada con los moriscos". Pero se aclara que para que la disposición tuviera efecto, los curas estaban obligados a tener padrón actualizado de sus feligreses; de no hacerlo, también a ellos se les sancionaría, y no con una "penilla moderada", sino con cinco o 10 pesos de oro, además de un castigo a arbitrio del ordinario en caso de segunda reincidencia.

Pena aún mayor (excomunión ipso facto y 20 pesos de multa), amenazaba a aquellos legos que, "sin tener suficiencia ni habilidad, ni ser su oficio, en las iglesias y fuera de ellas hacen juntar a los naturales y les predican y dicen cosas de nuestra santa fe, de lo que no estamos satisfechos pueda suceder bien ninguno, pues para el poder predicar a estas gentes tan nuevas debe hacer con mucha curiosidad y buscar causa y maña para les dar a entender nuestra santa fe" (41). Por su parte la constitución 48 ordenaba a los curas vigilar que tampoco se valiesen los legos de los edificios religiosos para menesteres ajenos a su naturaleza, como acostumbraban por ejemplo los tasadores de tributos, quienes incluso hacían tañer las campanas para reunir allí a los indios y llevar a cabo su labor. Quienes tal hicieren serían igualmente castigados con excomunión, como profanadores del templo.

Tampoco se mostraron "satisfechos" los cabildantes con la costumbre indígena de mantener, en las iglesias y en sus casas, "algunas imágenes de santos y santas y crucifijos pintados de manos de indios, las cuales en sus pinturas están mal dibujadas, que antes provocan a menosprecio y risa y no a devoción", por lo que ordenaron se recogiesen. Asimismo habrían de velar los eclesiásticos porque las imágenes restantes se tratasen con la reverencia debida, evitando en particular el que se tuviesen en sitios "no decentes" o expuestas al humo de "la candela" (43).

Engarzando con la constitución 44 , que como vimos ordenaba a curas y vicarios remitir al obispo a los casados que estuviesen separados de sus mujeres por más de dos años, la que le sigue enumera los casos cuya resolución quedaba reservada al diocesano. A los ya señalados en las propias sinodales se agregan aquí casos de incesto, aborto deliberado, amancebamiento público entre españoles, acceso carnal entre compadres, homicidio voluntario, ejercer violencia física sobre algún eclesiástico, herejía, sacrilegio, no pagar los diezmos y tomar cartas "mensivas", acaso por referencia a las 
misivas ${ }^{39}$ De igual tenor didáctico es la 47 , que recuerda a los curas los breves pontificios que contenían privilegios específicos para la Nueva España, a fin de que los diesen a conocer a sus feligreses.

El segundo párrafo de la constitución 49 (que en su primera parte se dedicó como vimos a los patrones, a fin de que enviaran a sus sirvientes a la doctrina), se antoja un franco añadido que, de algún modo, anticipa la conclusión del escrito al apuntar "Otrosí dejamos abierto este dicho sínodo para añadir lo que conviniere más al servicio de Dios nuestro señor, y para que cumplidamente sea proveído a lo tocante en buen gobierno de este nuestro Obispado."

La última disposición, la número 50 , se destinó a informar de la obligatoriedad de las constituciones previas, y a nombrar como responsables de vigilar por su cumplimiento a los curas de Naolingo, San Salvador, San Miguel, Guazacapán, Suchitepéquez y Huehuetlán; curatos, en buena medida por entonces bajo el control del clero secular, ${ }^{40}$ acaso previendo la oposición que ofrecerían los regulares a varias de las disposiciones.

\section{El destino inmediato}

Curiosamente sabemos más acerca de la conclusión del sínodo que de su inicio y marcha, gracias a que al final de las constituciones se señala que el 15 de octubre fueron leídas y publicadas desde el púlpito de catedral por el notario apostólico Lope de Villalobos, estando presentes el obispo, el gobernador Briceño, los integrantes del Cabildo Eclesiástico y "otros muchos clérigos, curas y vicarios de este Obispado que aquí firmaron sus nombres y prometieron de guardar y cumplir todo lo contenido en los dichos sinodales, so las penas en ellas puestas." Asistieron también al acto el procurador de la ciudad, y "otros muchos caballeros y ciudadanos", y fungieron como testigos don Francisco de la Cueva y diversos funcionarios civiles: "Juan de Guzmán, el secretario; Diego de Robledo, fator; Francisco de Ovalle, teniente de tesorero; Gregorio de Polanco y Alonso de Rosales, contador, oficiales de su majestad, y Carlos Bonifaz y Santos de Figueroa, alcaldes ordinarios; Diego de Bivar, alguacil mayor de esta ciudad y otros muchos vecinos y ciudadanos."

Cabe recordar que no era inusual se convocase a las principales autoridades civiles; de hecho, dada la existencia del Real Patronato su presencia era obligatoria, como se expresa claramente en la carta circular enviada por el obispo de Yucatán, Gómez de Parada el 25 de mayo de 1721, cuando "piadosa y doctamente apercibió al deán y Cabildo de su Iglesia, a los párrocos seculares y regulares, a los capellanes y clérigos, y al mismo tiempo al gobernador y capitán general de la Provincia, a los alcaldes de villas y ciudades y a los demás que por derecho deben ser convocados, para inaugurar el día seis de agosto del año próximo siguiente, en su catedral, el Sínodo..." (Eguiara y Eguren, op. cit., II: 782-783, cursivas nuestras).

${ }^{39}$ Denominación que en la época se aplicaba a las llamadas también cartas "familiares", de contenido estrictamente personal (Diccionario de Autoridades, op. cit., II: 202).

40 Incluyendo el de Huehuetlán, en la gobernación de Soconusco, en ese entonces adscrito al obispado de Guatemala. 
Una vez "publicadas" las resoluciones sinodales, el obispo, velando por su cumplimiento, mandó que todos los curas y vicarios acudiesen a lo largo del siguiente mes ante el notario autorizado a fin de obtener una copia. Pagarían por ella cinco pesos de oro "a costa de las fábricas de las iglesias de sus partidos, para que siempre quede en las dichas iglesias, para que por él los curas que son o fueren se rijan, guardando el dicho santo sínodo, y otro ninguno lo pueda dar autorizado, y lo firmó de su nombre."

Ignoramos si la disposición tuvo mayores efectos, pues apenas darse a conocer las resoluciones del Sínodo, varias de ellas fueron impugnadas por el fiscal de la Gobernación, Diego Ramírez, quien desde el 14 de octubre se dirigió al obispo haciéndole saber que

[... $\mid$ aunque muchas y las más cosas que ahí se leyeron están católica y cristianamente constituidas, hay algunas entre ellas que a mí, como a tal fiscal, convenía y conviene contradecirlas, y si lo he dejado de hacer al tiempo y sazón que se leían ha sido y fue porque ayer, dicho día, vuestra señoría dijo que allí no se tratase de contradicción alguna porque no fuese impedimento para continuar y efectuar el dicho sínodo y porque particularmente y por escrito se pidiese lo que por cada cual conviniese, que estaba presto de proveer lo que fuese obligado, conforme a Derecho, quitando, enmendando o añidiendo lo que conviniese, o proveyendo de nuevo aquello que más conviniese al servicio de nuestro señor y al bien de todos los súbditos de vuestra señoría [f 1].

Pasó luego a detallar aquello que juzgó le correspondía contradecir, que en esencia se reducía a cuatro puntos:

1) En "muchas" constituciones se ponía pena de excomunión y multas pecuniarias excesivas a los legos; en muchos casos incluso "dobladas" a las que se señalaban para sacerdotes y clérigos, pese a existir una "cédula real de su majestad por la cual ruega y encarga a los perlados y obispos de estas partes que a los legos no se excomulguen por cosas y casos livianos, ni se les eche ni impongan penas pecuniarias por muchos inconvenientes que de ello se seguían, según que en la dicha real cédula se contiene, de la cual hago presentación y pido y requiero a vuestra señoría la guarde y cumpla".

2) No era facultad del prelado exigir que se contase con su licencia para avanzar en la fábrica de las iglesias o adquirir ornamentos y otras cosas para el culto cuando se empleasen para ello "las haciendas de las comunidades y de los vecinos", pues en tales casos "ha de hacerse con licencia y parecer de la justicia real y no de otra manera, según que en esta provincia por los gobernadores que la han gobernado y gobiernan está proveído y mandado y se ha usado y usa y hace en cuanto a esto". Autorizar tales reparaciones o compras correspondería al poder eclesiástico sólo si para ello se empleasen "bienes propios de la dicha iglesia, de los cuales vuestra señoría y otro cualquier perlado podrá, conforme a Derecho, disponer por las dichas cosas".

3) Tampoco le correspondía legislar sobre lo relativo a la manera en que se deberían "cargar" los indios "y otras cosas semejantes", pues éstas eran materias ampliamente tratadas en cédulas y provisiones reales, y "porque estando por su majestad proveído, y prohibiéndolo generalmente a todas personas de cual- 
quier estado y condición que sean, en el dicho sínodo no se debió ni pudo prohibir." De paso, curándose en salud, contradijo al Sínodo "en todo aquello que es o puede ser en perjuicio de la jurisdicción y preeminencia real, y si es necesario es en cuanto acoto y en todo lo que por mí está contradicho, no lo enmendando vuestra señoría, apelo para ante su santidad y para allí donde de Derecho puedo y debo y pídolo por testimonio, etcétera."

4) Asimismo, le recordó al prelado su obligación, señalada por real cédula, de enviar al monarca y al Consejo de Indias las resoluciones tomadas en sinodos antes de hacerlas públicas de viva voz o imprimirlas.

En apoyo a sus reclamos, el fiscal adjuntó las dos reales cédulas a que se refería en su escrito, ambas fechadas en Toledo en agosto de 1560 y dirigidas a los arzobispos y obispos de Indias. En la primera, del día 27, el monarca señalaba haber sabido que algunos de ellos acostumbraban excomulgar a los fieles "por cosas y casos livianos", así como imponer penas pecuniarias a los legos "no se debiendo hacer. Y porque es tierra nueva donde se planta agora la fe, conviene tener gran templanza en cosa de descomuniones, así por lo que importa a buen ejemplo como por evitar escándalos". En consecuencia, les encargaba suspender tales sanciones, "porque no se dará lugar a que se haga lo contrario, por los inconvenientes de ello resultan." La segunda cédula, fechada cuatro días después, ordenaba a los prelados - tal y como sostenía el fiscal— enviar al Consejo de Indias, "en los primeros navíos", cualquier resolución tomada a lo largo de un sínodo antes de hacerla pública, para que éste determinase si su contenido no atentaba contra la jurisdicción real o podía provocar "inconvenientes y escándalos". ${ }^{41}$

Enterado oficialmente de los reclamos del fiscal el 15 de octubre, Villalpando prometió responder. Lo hizo el mismo día: nada había en lo decretado por el sínodo que fuese en contra de las reales cédulas que se le presentaron.

Así, en el caso de las excomuniones y penas pecuniarias a los legos, el obispo ${ }^{42}$ había tomado en cuenta tanto las reales cédulas como las disposiciones del Concilio de Trento. De hecho el sínodo había revocado "constituciones pasadas" que sancionaban con excomunión algunos actos livianos cometidos por legos, mientras que en éstas se circunscribía tal pena a dos casos particularmente graves como era el que no se confesasen durante la Cuaresma "y hasta la dominica tercera después de pascua de Espíritu Santo", como buenos cristianos ("que su majestad el rey nuestro señor así lo pretende"), y el que se atreviesen a predicar, en contra de lo ordenado por Trento, "atento que en estas partes hay más peligro de que los dichos legos prediquen a los naturales, por ser nuevos en nuestra santa fe católica y aparejados para recibir cualquier error que fácilmen-

${ }^{41}$ El 8 de marzo de 1619 Felipe III emitiría una real cédula que ordenaba a los prelados dar noticia al Consejo no sólo de lo que hubiesen legislado, sino incluso de lo hecho por sus antecesores y de "si se ha usado y usa de las dichas ordenanzas, acuerdos, constituciones y decretos, y si de alguno resulta perjuicio a nuestro patronazgo real o a otra materia pública" (Recopilación de Leyes de Indias, Libro II, Tit. I, ley XXXIV). El Título VIII del Libro I se dedica exclusivamente a "Los concilios provinciales y sinodales", pero exceptuando la reproducción de la cédula de Felipe II de 1560 (por cierto, con algunas variantes de poca monta) y otra de 1538 ratificada en 1549 (ordenando que en tales concilios se hiciesen aranceles para los eclesiásticos, ley IX), todas las leyes recopiladas son posteriores al período que aquí nos ocupa.

${ }^{42}$ Cabe destacar que la respuesta del prelado se da siempre en primera persona, sin aludir al Cabildo. 
te, predicándoles, los legos podrían decir". De limitarse a amenazarlos con pena pecuniaria, "está claro que... no lo cumplirán ni guardarán". ${ }^{43}$ Asimismo, de guiarse por el parecer del fiscal, "no se les podría mandar lo que conviene al bien y utilidad de sus ánimas debajo de ningunas penas, lo cual no es la voluntad ni intento de su majestad".

Ciertamente en otros casos no se señalaba excomunión sino sólo multas en dinero, pero correspondían a situaciones de menor gravedad conforme a lo estipulado por Trento en su sesión 24, capítulo tres, el cual determinaba "que en los casos que no fueren graves, en lugar de pena de descomunión se pongan penas pecuniarias". Y se trataba, recordase el fiscal, de un Concilio "mandado guardar por don Felipe, nuestro señor, rey de España, que viva por muchos años".

La segunda contradicción hecha por Ramírez, relativa a solicitar licencia episcopal antes de emprender mejoras en edificios u objetos para el culto, tampoco le parece atente contra la jurisdicción real; su único objeto es evitar que se repitan casos en que, una vez compradas "algunas cosas de los bienes de las comunidades", las justicias seglares no consintiesen se pagasen.

Y que para excusar lo dicho y dar orden, avisando a las dichas justicias seglares cuando fuere necesario y se hubieren de comprar las cosas necesarias para las dichas iglesias, demás de otros bienes de los que ellas tienen propios. Y para esto se hizo la dicha constitución, la cual, bien mirada, es en corroboración de la justicia y jurisdicción seglar y no contra ella, pues por ella no se prohibe que el lego que quisiere comprar algo para las iglesias y darlo de limosna no lo haga.

Otro tanto vale para la constitución que prohíbe cargar a los indios; no atenta contra lo ordenado por la Corona sino simplemente lo corrobora, recordándolo en particular a los clérigos que violentan en este punto la voluntad real.

¿Que debe enviar al monarca lo decretado por el sínodo? La real cédula que se le presentó fue emitida para corregir sínodos y constituciones hechos en contra de la jurisdicción real, y no es éste el caso. Todo lo acordado conviene al servicio de su majestad y a su real intención, amén de que ningún juez la ha empleado "sino es en caso de que algunas constituciones se hubiesen hecho contra Derecho, en perjuicio de la jurisdicción real, y así parece, pues en el sínodo celebrado en la ciudad de México por el reverendísimo arzobispo y obispos congregados, se halló presente toda la Audiencia Real y el visitador, [el] licenciado Balderrama, y no hubo contradicción alguna, ni presentaron cédula, ni el fiscal pidió cosa alguna".

Y tampoco se registró contradicción "en los sínodos fechos por su antecesor, de buena memoria, en esta ciudad, en tiempo que aquí estaba la Real Audiencia," ${ }^{44}$ pese a que en ellos se instituían excomuniones y multas en dinero contra aquellos legos que incurrían en pecados mortales, "considerando justamente no ser la voluntad de su ma-

\footnotetext{
${ }^{43}$ Agrega Villalpando que "atento a que su intención es de que se guarde y no llevarles pena pecuniaria", aseveración por demás curiosa ya que la constitución impugnada (la número 41) sanciona a los transgresores con excomunión y 20 pesos "aplicados para los gastos de las iglesias donde el dicho hiciere la dicha predicación" (vid infra).

${ }^{44}$ Como apuntamos al inicio del artículo, para ese entonces Guatemala había sido colocada de nuevo bajo la jurisdicción de la Audiencia de México.
} 
jestad prohibir que en semejantes casos no se pongan penas de excomunión y pecuniarias". Pese a ello, estaba de acuerdo en entregar al fiscal el testimonio que pedía (pero aclarando que éste debería ir acompañado de su respuesta), "para que a su majestad le conste cuan justa y santamente estaba hecho y ordenado". De hecho, él mismo enviaría un traslado del sínodo al rey, pues a Diego Ramírez, "su señoría reverendísima dijo que no le conocía ni le conoció por fiscal de su majestad, ni le consta que lo sea". Para rematar, recordó que el mismo Trento ordenaba a los diocesanos realizar sínodos, y que el monarca, "como rey católico, ha mandado se guarde y cumpla el santo Concilio Tridentino sin aditamento", y sin pedir expresamente le enviasen copia de los sínodos realizados.

No sería sino hasta tres meses después cuando Diego Ramírez continuase con su intento. El 27 de enero de 1567 se presentó ante el provisor de la Gobernación, el licenciado Remón y le solicitó mediase para que le fuera entregado testimonio de la impugnación que había hecho del sínodo, que según dijo le negaba el notario episcopal, Lope de Villalobos, alegando que no se la podía entregar si no iba junto con él la respuesta del obispo. Ni la respuesta ni lo contenido en el sínodo, apuntó, le interesaban; en todo caso era obligación del obispo, y no suya, enviar copia de ello al Consejo. Únicamente exigía, para cumplir con su oficio, "el testimonio de cómo presente la dicha cédula y petición". El provisor ordenó al notario atender a la solicitud, pero sin limitarse a ello, pues mandó se le entregase "el dicho testimonio como por su señoría reverendísima está mandado y no de otra manera". En consecuencia, se anexó al expediente un traslado de las constituciones emanadas del sínodo. Gracias a ello contamos hoy con el texto completo.

Ignoramos hasta qué punto la controversia con los funcionarios reales retrasó o incluso impidió la puesta en marcha de lo ordenado en el sínodo, y si bien Remesal asegura que "usaban" de él "y le hacían guardar sin haberle enviado a Consejo, contra el orden y privilegio que el rey tiene, que se ha guardado siempre" (op. cit.: 499), no deja de parecer significativo el que no se haya podido ubicar copia alguna siquiera en el $\mathrm{Ar}$ chivo Histórico Arquidiocesano de Guatemala, ni se le mencione por ejemplo en las visitas pastorales llevadas a cabo por los sucesores de Villalpando, donde a menudo se alude a disposiciones y decretos previos. ${ }^{45}$

En junio de 1594 el obispo Gómez de Córdoba ordenó copiar en el Libro de Cabildo las disposiciones dadas por Marroquín cuando Guatemala se erigió en Diócesis, mientras que en 1604, cuando su sucesor Juan Ramírez de Arellano mandó poner juntas las constituciones y ordenanzas de sus antecesores para que no se olvidasen " $y$ para que se lean en los días que de yuso irán señalados para que todos sepan lo que han de hacer, y así los prebendados como los capellanes y sacristanes cada uno acuda a su oficio a su tiempo y hora", se refirió exclusivamente a las de Marroquín y a las dadas por el Cabildo Sede Vacante en $1564 .{ }^{46}$ Ninguna referencia a las surgidas bajo el gobierno de Villalpando.

\footnotetext{
${ }^{45}$ Véanse, como ejemplo, las numerosas referencias que aparecen en los tres tomos ya editados de dichas visitas pastorales (Ruz et al., 2002 y 2004).

${ }^{46}$ Ruz, De Paz y Vicencio, op. cit., t. II.
} 
¿Cómo explicar el olvido o la deliberada negación? ¿Corrieron acaso las disposiciones de don Bernardino una suerte similar a las constituciones realizadas por el obispo de Chiapa Núñez de la Vega a finales del siglo xvı y publicadas subrepticiamente en Roma en 1702 , que terminaron proscritas por la Corona, requisadas y quemadas ${ }^{47}<0$ simplemente se les soslayó a nivel oficial como ocurrió con las decretadas en Yucatán en 1722, bajo la mitra de Juan Gómez de Parada? ? $^{48}$

Es difícil saberlo. Sin duda los tiempos eran distintos. Cuando tanto las chiapanecas como las yucatecas se intentaron poner en ejecución, la Monarquía hispana estaba ya bajo los Borbones, bastante más preocupados por afianzar el poder real que sus últimos antecesores Habsburgo, pero tampoco puede obviarse que el intento de Villalpando se sitúa en época de Felipe II, cuya administración difícilmente puede considerarse como laxa en lo que a conductas regalistas toca. Sea como fuere, es claro que se requiere una investigación específica para historiar el destino e impacto que tuvieron las disposiciones emitidas por el obispo y su Cabildo, pero hacerlo rebasa los objetivos de este breve comunicado cuya única finalidad es poner en manos de los estudiosos tan importante texto, rescatándolo del olvido a casi 450 años de su elaboración.

\footnotetext{
${ }^{47}$ Sobre este particular véase el estudio introductorio de la re-edición del texto (1988).

${ }^{48}$ Apunta Eguiara: "Acerca de este Sínodo, en los Monumentos de la Iglesia de Guatemala (adonde había sido trasladado de Yucatán el Ilmo. Parada), editados por Fr. Raymundo Leal, de la Orden de Predicadores, el año de 1744 , después de otras cosas, encontramos en la página 55 , que después de más de veinte años no ha podido ser impreso, pues todavía está detenido en manos de los reales ministros, que indagaban si en él no hay cosa que afecte los derechos del rey" (op. cit. t. II, pp. 782-783).
} 


\section{[CONSTITUCIONES SINODALES DEL OBISPADO DE GUATEMALA $]^{49}$}

Don Bernardino de Villalpando, doctor en santa teología, por la gracia de Dios [y] de la santa Iglesia de Roma, obispo de esta ciudad de Santiago de Guatimala, Indias del Mar Océano, del Consejo de su majestad, etcétera, a los reverendos hermanos deán y Cabildo de esta santa Iglesia y a los demás curas y vicarios de este nuestro Obispado y a los católicos y fieles cristianos, salud espiritual en Jesucristo, nuestro maestro y redentor.

En el principio de la creación del mundo, cuando por Dios fueron creadas todas las cosas, especialmente la natura angélica, como nos enseña el primer libro del Génesis, fue criada y dotada de muchas virtudes y gracias y de tantas excelencias y prerrogativas que, viéndose Lucifer tan dotado, con soberbia se quiso igualar a su creador. $\mathrm{Y}$ aunque esta igualdad, como dicen los santos doctores, no fue quererse equiparar a Dios, que esto fuera contra natura, quiso tener alguna semejanza con el mismo Dios. Y viendo Dios su malicia y su soberbia, en un punto lo derribó de lo alto de la bienaventuranza y le condenó [f $4 \mathrm{v}$ ] a perpetua pena del Infierno a él y a sus sec[u]aces. Y porque las sillas que aquellos malos por su soberbia perdieron no quedasen vacías, ordenó por su infinita misericordia y sabiduría de criar la naturaleza humana.

Lucifer, teniendo envidia al hombre, procura estorvalle [estorbarle] esta bienaventuranza y para ello escogió un género de serpiente que -según la opinión de muchos doctores- en aquel tiempo andaba derecha y tenía la cabeza como mujer, y con esta serpiente acometió a lo más flaco, que fue nuestra primera madre Eva, y la engañó, y ella a nuestro padre Adán, y así traspasaron el mandamiento que Dios les había puesto en el Paraíso Terrenal, por cuyo pecado toda la naturaleza humana quedó obligada a perpetua cárcel del Infierno hasta que Dios nuestro señor ordenó de enviar su unigénito hijo al mundo para que nos diese ley de gracia y orden de vivir.

$\mathrm{Y}$ aun antes que Cristo nuestro redentor viniese en [sic por a] este mundo como cosa conveniente y aun necesaria, en la ley del Testamento Viejo hallamos Dios nuestro señor haber gobernado el pueblo de Israel, escogido por sus ministros, jueces, profetas y últimamente por reyes como la sagrada escritura nos lo muestra en el capítulo primero de Los Jueces y en el capítulo primero del libro de Los Reyes, por los cuales fueron dadas leyes al pueblo de Israel, cuyo poder duró hasta que Cristo nuestro redentor vino en [sic por a] este mundo, rey verdadero, señor universal, sacerdote in eternum según la orden de Melchisedec, cuyo poder espiritual dejó a san Pedro y después de él a sus sucesores, los legítimos pontífices romanos.

Y el poder temporal ha venido de unos reyes en otros, especialmente en los que han recibido su santa fe para que con su favor el poder espiritual sea ayudado y favorecido contra los rebeldes y malos cristianos, haciéndoles guardar y tener la fe que en el santo bautismo prometieron, y para que su santa fe fuese en diversas partes del mundo

\footnotetext{
49 Presentamos el texto modernizado en cuanto a ortografia y puntuación, excepto en el caso de topónimos, nombres propios y locuciones latinas, que se mantuvieron sin modificar pese a los francos errores que se advierten en estas últimas. En caso de tratarse de arcaísmos o voces hoy poco usuales, colocamos entre corchetes su equivalencia cuando bastaba con un sinónimo, o los explicamos en nota al pie si la explicación requerida era más larga. Corregimos, asimismo, las faltas de concordancia en género y número.
} 
predicada, como ha sido en estas partes con el favor y por medio del cristianísimo emperador de gloriosa memoria, señor nuestro, ${ }^{50}$ y del cristianísimo don Felipe, rey de España, señor nuestro, que viva por muchos y dichosos años, [gracias a] los cuales, con infinitos gastos y diligencia y celo cristianísimo de verdaderos reyes y señores, la fe de Jesucristo nuestro redentor en estas partes tan remotas está extendida, donde es alabado entre estas gentes bárbaras que tantos años sin conocimiento de Dios nuestro señor han estado idolatrando su santísimo nombre y ofendiéndole con multitud de pecados y hasta los tiempos felicísimos de nuestros reyes y señores.

Y nos, deseando imitar a los santos ministros de Dios y apóstoles, en cuya imitación nuestra santa madre Iglesia romana, para reformación [f 5 ] de los fieles cristianos, ha congregado muchos y diversos y generales sínodos ${ }^{51}$ regidos por el Espíritu Santo para bien de este pueblo a nos cometido, y para le dar pasto saludable y para refrenar las malas costumbres hemos ordenado este santo sínodo en constituciones, en cumplimiento de lo que somos obligados y nos es mandado por el santo Concilio Tridentino, como hijo de obediencia de la santa madre Iglesia de Roma, para lo cual llamamos a nuestros curas y vicarios y para recibir y jurar el santo Concilio Tridentino y todo lo en él ordenado, el cual celebramos en este año de 1566 años con los reverendos deán y Cabildo y los demás curas y vicarios, invocada la gracia del Espíritu Santo, hicimos y ordenamos en esta santa iglesia catedral las constituciones siguientes:

\section{Constitución 1}

Que todos [los] fieles cristianos guarden el santo Concilio Tridentino.

Primeramente como hijos de obediencia de la santa madre Iglesia de Roma recibimos el Santo Concilio Tridentino y lo juramos y guardamos; sea guardado y cumplido en este nuestro Obispado por todos los fieles. Y guardándolo y cumpliéndolo todos nuestros curas y religiosos que tienen administración y beneficios curados en este nuestro Obispado con nuestro beneplícito $[s i c \mid$ vendrán ante nos dentro de 15 días de la publicación a hacer la profesión de la fe, según y como por el dicho santo Concilio está determinado en la sesión 24 , capítulo 12.

Otrosí, conformándonos con el dicho santo Concilio Tridentino, y para que sea guardado y cumplido lo en él determinado en la dicha sesión 24 , capítulo 15 , nombramos por examinadores para que los tales proveídos en este nuestro Obispado por nos sean examinados conforme la dicha sesión y capítulo, a nuestro provisor que es o fuere y [a] don Francisco de Peralta, arcediano de esta santa iglesia y a don Pedro de Liévana, chantre tesorero, don Martín Díaz y canónigo Cambranes y a Antonio de Ávila, clérigos presbíteros, y mandamos a los tres de ellos -por la orden que en esta nuestra sinodal está determinado- conforme al dicho santo Concilio hagan la dicha examinación. De lo cual todos los por nos proveídos llevarán de nuestro notario un tanto de lo tocante al parentesco espiritual determinado por el santo Concilio, para que sea publicado en

${ }^{50}$ Carlos I de España y V de Alemania.

${ }^{51}$ En el texto se anota siempre "sígnodo" o "sígnodos", en ocasiones en femenino: "esta santa sígnodo". 
sus iglesias conforme a como en esta [ $5 \mathrm{v}$ ] santa iglesia se ha publicado, asentando en los libros de las tales iglesias el día, mes y año que se publica, dando a entender a los dichos naturales lo en ello contenido, so pena que el trasgresor será castigado.

\section{Constitución 2}

Otrosí, S. A. S. ${ }^{52}$ ordenamos y mandamos que en este nuestro Obispado sea guardado y se guarde y cumpla por nuestros curas y vicarios y por los vecinos y moradores, estantes y habitantes en él, [el] sínodo provincial celebrado en la ciudad de México por el reverendísimo arzobispo de la dicha ciudad, nuestro metropolitano, y los demás prelados; el cual sea guardado so las penas en él contenidas, demás que serán por nos los transgresores castigados.

\section{Constitución 3}

Cosa es muy conveniente para el aprovechamiento de estos naturales que las cosas de nuestra santa fe católica se les dé a entender por nuestros ministros, así de palabra como de obra, declarándoles el santo evangelio y los santos sacramentos de nuestra santa madre Iglesia y porque la administración de los santos sacramentos se les ha de administrar de gracia y sin les pedir ni llevar cosa alguna, y porque en algunas partes de este nuestro Obispado hay algunas malas costumbres y por imposiciones a los indios y naturales se les pide por la administración de ellos especialmente, haciéndoles ofrecer por fuerza, S. A. S. ordenamos y mandamos que de aquí adelante ningún sacerdote por sí ni por interpósita persona direte ni indirete ${ }^{53}$ sea osado de pedir en público ni en secreto por la administración de los santos sacramentos ninguna cosa ni dinero, ni haga -por sí ni por interpósitas personas- a los dichos naturales le ofrezcan cacao, dinero, mantas ni otra cosa, ni haga que los alguaciles del pueblo donde tuviere él administración, los días ${ }^{54}$ que, conforme al sínodo pasado celebrado en esta ciudad por nuestro antecesor de buena memoria, deben ofrecer, anden [tales alguaciles] por las calles diciendo a los dichos naturales que lleven que ofrecer, pues las dichas ofrendas deben de ser de voluntad. Y solamente permitimos a los dichos curas y ministros del santo evangelio que la fiesta antes del día de la ofrenda les digan y declaren cómo la fiesta que se sigue es día de ofrenda, [para que] el que quisiere pueda ofrecer, declarándoles el premio y valor que las ofrendas tienen ante el acatamiento de Dios, y como puramente deben ser hechas de voluntad, so pena que al que lo contrario[f 6$]$ hiciere incurra por la primera vez en pena de 50 pesos de oro aplicados la mitad para la iglesia del pueblo donde hiciere lo contrario y la otra mitad para el acusador y juez que lo sentenciare, y por la segunda la propia pena y destierro de este nuestro Obispado perpetuo, y desde luego lo condenamos en las dichas penas.

52 ¿Sub amonestatione sententia?

53 Directa ni indirectamente.

54 Tachado: "yndios". 


\section{Constitución 4}

Y porque nuestra santa madre Iglesia tiene determinado [que] los fieles cristianos deban ofrecer los días de fiesta -por ser las ofrendas santas y buenas y de mucho mérito delante el acatamiento de Dios y así está determinado por muchos concilios- y principalmente son obligados a ofrecer cuando los ministros del santo evangelio no han otra cosa donde se sustentar, como en estas partes, y agora las ofrendas no son como solían y nuestros ministros padecerían necesidad por no habèr otra cosa donde se sustentar si no les ofreciesen y si no se proveyese del remedio, por ser los indios naturalmente descuidados en las cosas de nuestra santa fe católica e inclinados a tomar los consejos que les dan, somos informados que muchos españoles, o por mala voluntad que tienen a nuestros ministros o por otros respetos, inducen a los naturales y les atraen a que no ofrezcan, en lo cual Dios nuestro señor se ofende y es mala doctrina y a los dichos naturales se les muestra, pues deben de ser enseñados a que los hagan y dalles [darles] a entender el valor que ante Dios tienen [y] cómo aprovechan a los vivos y a los difuntos, por ende, S. A. S. ordenamos y mandamos que ninguna persona de cualquier dignidad y calidad que sean, no sea osado por vía directa ni indirete, pública ni secretamente, por sí ni por otra persona, de decir a los naturales que no ofrezcan, pues nuestra santa madre Iglesia lo permite y manda.

$\mathrm{Y}$ si alguno fuere tan temerario que traspasare esta nuestra sinodal, por el propio hecho ponemos y promulgamos en él seña de descomunión mayor, a nos reservada. Y rogamos y encargamos a todos los fieles cristianos que supieren alguno de nuestros ministros exceder de lo establecido en las sinodales de este Obispado nos den aviso para que por nos sea castigado.

\section{Constitución 5}

Ítem, gran diligencia debemos tener [en vigilar] que todo fiel cristiano cumpla el precepto de nuestra santa madre Iglesia y se confiese a lo menos una vez en cada un año. Y para que así esto se guarde y cumpla, así los naturales -pues de ello son obligados por haber recibido [ $\mathrm{f} 6 \mathrm{v}$ ] el santo bautismo y fe de Jesucristo-como en todos los demás españoles, mestizos, mulatos y negros, S. A. S. ordenamos y mandamos que todos los curas y vicarios de este nuestro Obispado, cada uno en su parroquia, sea obligado a tener padrón de sus feligreses para que por él se sepa qué personas son las que no han cumplido el precepto. Y para que no haya fraude ninguno de aquí adelante en las personas que dicen haberse confesado no lo habiendo fecho, nuestros curas en los pueblos de los españoles no darán por confesada a ninguna persona que no trujere [trajere] cédula del confesor, clérigo o religioso que le haya confesado. Y encargamos y rogamos a los religiosos de las órdenes que con nuestra licencia confesaren, que a todos los que con ellos se confesaren -españoles, mestizos, mulatos y negros- les den la dicha cédula y tengan su padrón donde se asienten lo que así confesaren, para que pasada la Cuaresma lo den y entreguen a nuestro cura para que se sepa los que no han confesado. $Y$ entre los naturales, nuestros curas y los religiosos que los tuvieren a cargo 
tendrán padrón de los que confesaren para que por él vean y entiendan si han confesado todos sus feligreses. El cual dicho padrón nos enviarán después de Pascua, con relación de los vecinos que el dicho pueblo tuviere, para que veamos qué ta[n]tos de ellos se han confesado. Y a los demás que no se hubieren confesado en la Cuaresma procurarán de los confesar y atraer al santo sacramento de la confesión con palabras santas y buenas para que verdaderamente los dichos vengan al sacramento de la confesión. Lo cual cumplan y guarden los dichos nuestros curas so pena de 20 pesos de oro, la mitad para gastos de la iglesia del pueblo de los naturales donde residiere y la otra mitad para el acusador y juez que los sentenciare. $Y$ a los dichos religiosos les encargamos y encomendamos así lo hagan y cumplan.

\section{Constitución 6}

Ítem, y porque nuestra intención es que así los españoles, nuestros súbditos, como los mestizos, mulatos, negros y naturales, todos se confiesen y sepan lo demás tocante a nuestra santa fe católica para que mejor sea guardado y cumplido y ninguno se quede por confesar, por cuanto los vecinos y moradores de esta ciudad y los demás vecinos de las otras ciudades y villas y lugares de este nuestro Obispado, en sus estancias y labranzas y otras granjerías que tienen, tienen muchos criados mestizos, mulatos, negros e indios e indias, y de ellos no tienen el cuidado que se debe tener, para remedio de lo dicho S. A. S. ordenamos y mandamos a los dichos españoles y señores de las tales estancias y granjerías que al tiempo que por nuestros curas se hiciere padrón en las dichas ciudades [f 7], villas y lugares donde los tales fueren vecinos y tuvieren las tales estancias, digan y declaren los criados españoles, mestizos, mulatos, y negros, indios e indias que tienen en sus dichas haciendas, y cómo se llaman, y los tales curas sean obligados a los empadronar para que por el término por nosotros señalado, no trayéndoles cédulas de cómo están confesados, los declaren por descomulgados. Y a los tales señores de las tales estancias les mandamos, so pena de descomunión, [que] al tiempo que dicho padrón se hiciere declaren los dichos criados que tienen en las dichas estancias y sus haciendas, y sepan que no trayendo cédula al cura se declararán por descomulgados y se procederá contra ellos. Y aunque las dichas estancias no estén en términos de las tales ciudades, villas y lugares, sean obligados a traer las dichas cédulas del cura o religioso que los confesare, so la dicha pena.

\section{Constitución 7}

Ítem, otrosí, porque todos los fieles cristianos se confiesen y haya tiempo para que los que no se pudieren confesar dentro de la Cuaresma por algunas ocupaciones justas, S. A. S. ordenamos y mandamos que con el dicho precepto cumplan asimismo los que se confesaren después de Cuaresma y hasta el tercer domingo después de Pascua de Resurrección. Y si alguno fuere tan temerario que dentro del dicho término no cumpliere con el precepto de nuestra santa madre Iglesia, desde agora para entonces ponemos y 
promulgamos en el señal de descomunión y de cinco pesos, en que asimismo le damos por condenado lo contrario haciendo, aplicados para la fábrica de esta santa iglesia, lo cual haya lugar en los españoles, mestizos, mulatos y negros para que sus amos y señores tengan cuidado de los hacer confesar, pues a ello son obligados.

\section{Constitución 8}

Aunque por derecho es permitido que se pueda confesar por intérpetre [sic], aquello se entiende cuando de otra manera no se puede oír de penitencia por ser [de] diferente lengua el penitente que el confesor, y aunque al principio en estas partes hubo falta de lenguas, por la gracia de Dios en este nuestro Obispado ha cesado la necesidad que solía haber, y casi todos o la mayor parte de los ministros del santo evangelio saben la lengua mexicana, común en este Obispado. Por lo dicho, es razón que, pues no hay necesidad, se tenga gran cuidado que ninguno se confiese por intérprete y así, S. A. S. ordenamos y mandamos que ningún clérigo ni religioso de ningún estado que sea confiese ninguna persona en este nuestro Obispado por intérprete, lo cual guarden y cumplan, so pena que el clérigo que tal confesare será castigado en 50 pesos de pena, aplicados la tercia parte para los ornamentos y gastos de la iglesia donde estuviere y tercia parte para el acusador y nuestra Cámara y la otra tercia parte para el juez que lo sentenciare, por la primera vez, y por [f $7 \mathrm{v}$ ] la segunda, privación de beneficio.

$\mathrm{Y}$ porque algunos de nuestros clérigos que vienen nuevamente de España, necesariamente han de deprender ${ }^{55}$ la lengua entre los naturales y en tanto que la aprenden no pueden confesarlos, mandamos que el clérigo más cercano que la supiere, siendo por el tal clérigo llamado, vaya a su Partido y confiese a los dichos naturales o nos avise para que en el tiempo de la Cuaresma enviemos confesor que sepa la lengua y le ayude.

A los religiosos encargamos no confiesen por intérprete según por este sínodo está determinado y mandado, porque así conviene y es nuestra voluntad.

\section{Constitución 9}

Ítem, y porque en los pueblos de los naturales y de los españoles en este nuestro Obispado andan muchos españoles, mestizos, y mulatos tratantes, los cuales - por no tener casa conocida en esta ciudad ni en otra parte- siempre que por alguno de nuestros curas se le pide y demanda cuenta dónde se han confesado, se excusan diciendo, si se les pide en Guatimala, que se confesaron en Zonzonate, y si se la piden en otro pueblo dicen que se confesaron en otro, y con esta ocasión viven mal y no conforme a cristianos, y porque conforme a Derecho Canónico los tales son del fuero y jurisdicción donde más a la continua habitan y están, y porque es razón que en esto se ponga remedio y se les tome cuenta a los tales si son cristianos y den cuenta dónde sean confesados y a todos si saben la doctrina, especialmente a los mestizos y mulatos e indios tratantes, S. A. S. ordenamos y mandamos que los tales en el tiempo de Cuaresma, en el

55 "Aprender", voz considerada actualmente arcaísmo. 
Partido o pueblo de españoles o indios, nuestros curas y vicarios y el religioso que tuviere a cargo el dicho pueblo y visita les tome cuenta de la doctrina y si están confesados y dónde y con quién, y no lo mostrando, o dando cédula del clérigo religioso conocido que los haya confesado, nos dé aviso para que se haga justicia. Y si no estuviere el tal confesado, damos licencia al cura y vicario o religiosos en cuyo Partido se hallare [para que] lo pueda confesar y confiese como si fuese su feligrés. Y la dicha cuenta tendrán nuestros curas vicarios, so pena de ser castigados a nuestro arbitrio.

Y si alguno de los tales no hubiere confesado en toda la Cuaresma hasta la dicha dominica tercia ego sum parti bonus, nos lo remitan para que se haga justicia sobre ello.

\section{Constitución 10}

Ítem, porque en las confesiones es donde son más aprovechados estos naturales y por los ministros del santo evangelio atraídos al servicio de Dios nuestro señor y lugar santo donde mejor son reprehendidos de sus vicios y pecados, para que ninguno quede por confesar ni pierda tanto beneficio, S. A. S. encargamos y rogamos a los religiosos de las órdenes que, siendo por algunos de nuestros curas y vicarios llamados para les ayudar a confesar sus feligreses por estar impedidos o enfermos por otro impedimento que suele acaecer, le ayude a confesar los feligreses, pues es obra meritoria y de caridad, y de las obras que ellos suelen y acostumbran hacer.

\section{Constitución 11}

[f 8] Necesaria cosa es para la conversión de los naturales que los ministros del santo evangelio sepan la lengua, pues sin ella no pueden ser ministrados en las cosas tocantes a la santa fe católica y los sacramentos de la santa madre Iglesia. Por ende, S. A. S. ordenamos y mandamos que todos los curas y vicarios tengan gran cuidado y diligencia de aprender la lengua de sus partidos, con el mayor cuidado y diligencia que pudieren, so pena que serán castigados a nuestro arbitrio. ${ }^{56}$

\section{Constitución 12}

Todo fiel cristiano debe saber las cuatro oraciones de la santa madre Iglesia y artículos de nuestra santa fe y mandamientos de Dios y de la Iglesia $[y]$ pecados mortales. Por ende, S. A. S. ordenamos y mandamos que todos los domingos y fiestas de guardar, cada cura en su Partido tenga especial cuidado de hacer juntar todo el pueblo y por uno de los dichos naturales que lo sepa, por él examinado, les muestre, diga y enseñe las cuatro oraciones, artículos de la fe, mandamientos de la Iglesia y sacramentos $[\mathrm{y} \mid$ pecados mortales, demás de que tendrá cuidado de que ordinariamente cada día haga juntar los niños y niñas pequeños a la escuela, donde sea mostrado lo susodicho.

${ }^{56} \mathrm{El}$ texto asienta adbitrio, vocablo que sustituimos por el moderno arbitrio. 
Y porque por los religiosos de señor santo Domingo, y para mejor ser industriados los dichos naturales, se han hecho ciertas preguntas y respuestas tocantes a nuestra santa fe, muy buenas y santas, mandamos a los dichos rectores y curas que por nos fueren proveídos pidan a nuestro notario un tanto, y aquellas se les enseñen y hagan deprender, poniendo un indio en una parte de la iglesia donde estuviere todo el pueblo junto, al cual pregunte otro indio las dichas preguntas y el dicho las responda con todo el pueblo.

Y porque en algunas partes están impuestos los dichos naturales a cantar en las iglesias, en lugar de las horas canónicas, las horas de Nuestra Señora y esto lo cantan en latín y no entienden lo que dicen ni de ello reciben provecho, mandamos que, en lugar de lo dicho, nuestros curas y vicarios hagan que los dichos naturales canten en su lengua las cuatro oraciones y lo demás aquí contenido, demás de que tendrán cuidado de, a chicos y grandes, las dos pascuas del año, Navidad y Pascua de Espíritu Santo, particularmente a cada uno de sus feligreses, tomarles cuenta si saben todo lo aquí contenido, y los que no lo supieren sean reprehendidos y procuren que lo sepan, lo cual mucho les encargamos guarden y cumplan, so pena de ser gravemente castigados.

\section{Constitución 13}

Otrosí, S. A. S. ordenamos y mandamos a los dichos nuestros curas y vicarios que de aquí [en] adelante no absuelvan a ningún español ni mestizo, hombre ni mujer, de ningún estado que sea, que no supiere las cuatro oraciones de la Iglesia y mandamientos de la ley de Dios y de la Iglesia, artículos de fe, sacramentos, explícitamente que es, por orden o sin ella, y la dicha absolución se la suspendan hasta que lo traigan sabido. En los demás: indios [f $8 \mathrm{v}$ ], negros y mulatos, conforme al talento de cada uno, nuestros curas se hayan con ellos como les pareciere conviene a la salud de las ánimas de los tales.

\section{Constitución 14}

Siempre esta santa Iglesia se ha regido conformándose en el rezar el oficio divino conforme a la santa Iglesia de Sevilla y así se ha guardado desde su principio y erección y se debe guardar en todo este nuestro Obispado, así en el oficio mayor como el menor. [Por tanto] S. A. S. ordenamos y mandamos que así se guarde y cumpla, y guardándolo y cumpliéndolo mandamos que en las misas cantadas el sacerdote vaya rezando lo que se hubiere de rezar en el altar conforme y al tiempo que se va cantando en el coro, y ningún clérigo pueda rezar las horas canónicas que es obligado por otro breviario que [no sea] el sevillano, si no fuere teniendo breve de su santidad para lo poder hacer, lo cual guarden y cumplan con apercibimiento que serán por ello castigados. 


\section{Constitución 15}

Según Derecho, ningún clérigo ni religioso en este nuestro Obispado puede administrar los santísimos sacramentos de nuestra santísima madre Iglesia sin nuestra especial licencia, y pues tenemos nuestro cura en esta santa iglesia catedral y ser razón que a ella vengan todos los vecinos a recibir los santísimos sacramentos y así los demás pueblos a las iglesias de ellos, S. A. S. ordenamos y mandamos que ningún clérigo ni religioso de las órdenes, en sus casas ni monasterios en esta ciudad, no desposen, velen, ni bauticen, porque asi declaramos ser nuestra voluntad. Lo cual guarden y cumplan so las penas del Derecho.

\section{Constitución 16}

Con gran reverencia y con mucha santidad debe cualquier cristiano llegarse a recibir el santísimo sacramento de la comunión y con gran diligencia debe examinar su conciencia para le recibir dignamente conforme a lo que nos dice el apóstol: qui manducat et bivit indigne juditium sibi manducat et biuit non iudicans corpus Dominii. Y porque esta santidad y examen tan diligente de conciencia, por ser tiernos aún en la fe de nuestra santa madre Iglesia, los naturales, negros y mulatos, y les falta esta limpieza de conciencia, y la santa madre Iglesia tiene declarado haber de ser de tal manera que ninguno con conciencia de pecado mortal se llegue a tan alto sacramento, para que a los a tales no se les dé ocasión a que en lugar de salud espiritual-porque entendemos que esta limpieza les falta- reciban condenación, conforme a lo del apóstol y determinado por el santo Concilio, sesión 23, capítulo 7, agora en tanto que son tiernos en nuestra santa fe, S. A. $\mathrm{S}$. ordenamos y mandamos que a los tales na[f 9|turales, negros y mulatos no se les administre por ningún clérigo ni religioso este santísimo sacramento de la comunión.

$\mathrm{Y}$ porque algunos hay buenos cristianos que merecen gozar de tan alto bien, encargamos al confesor que los confesare nos dé aviso a nos o nuestro provisor y visitadores si se les deben administrar el santísimo sacramento de la comunión para que se lo administre y goce de tan alto bien, y sin el dicho aviso ningún clérigo ni religioso se lo administre, lo cual les encargamos sea guardado y cumplido porque así es nuestra voluntad.

\section{Constitución 17}

Por cuanto por el santo Concilio celebrado en Trento está ordenado y mandado que ningún sacerdote ni religioso de ninguna calidad que sea no celebre [la misa] en casa particular ni en parte alguna que no sea iglesia y lugar decente y determinado para tan alto sacramento, y para que ningún sacerdote de ninguna dignidad ni calidad que sea, pretendiendo ignorancia, traspase el santo Concilio, S. A. S. ordenamos y mandamos que así lo guarden y se cumplan en este nuestro Obispado, so pena de 50 pesos, aplicados la mitad para la fábrica de esta santa iglesia y la otra mitad para el acusador y juez que lo sentenciare. 


\section{Constitución 18}

Porque el santísimo sacramento de la extremaunción se debe dar a los que están en el artículo de la muerte y lo pidan y muestren señales de pena y contrición, para corroboración del espíritu contra la flaqueza del pecado y para limpiar las reliquias que quedan del pecado, para que estos naturales gocen y consigan la gracia de este santo sacramento S. A. S. ordenamos y mandamos que todos nuestros curas y vicarios y religiosos que a cargo tienen estos naturales, que luego que confesaren a cualquiera de ellos les digan si quieren recibir el santo sacramento de la extremaunción, declarándoles la gracia que por él se recibe. $\mathrm{Y}$ viendo señales por [d]onde le merezca recibir, mandamos a nuestros curas y encargamos a los religiosos que a cargo tienen los dichos naturales, a los cuales pareciere ser justo se lo administren, procurando que toda decencia se haga la dicha administración y les encarga|m|os de aquí adelante que [en] los sermones le declaren esta sinodal, para que en sus casas tengan toda [la] limpieza que conviene.

\section{Constitución 19}

En esta santa iglesia todos los terceros domingos de cada mes del año se dice una misa a la Cofradía del Santísimo Sacramento y se hace procesión por la iglesia con el santísimo sacramento, fiesta a que ningún parroquiano ni vecino debe faltar, [en] especial los que son cofrades del santísimo sacramento y que por tal día no ser razón que de nuestra iglesia falten los fieles, ni haya ocasión para que dejen de venir a tan alta fiesta, y que por la gente es poca y habiendo fiesta en otra parte no viene ninguno, declaramos ser nuestra voluntad, S. A. S., que en los tales días, terceros domingos de cada mes, en ningún monasterio haya sermón, pues es más razón que vengan los [f $9 \mathrm{v}$ ] fieles cristianos a la procesión del santísimo sacramento. Y rogamos a los religiosos que si en los tales días o en otros que se hiciere fiesta en nuestra iglesia tuvieren fiesta que celebrar, por la dicha razón la pasen a otra fiesta siguiente.

\section{Constitución 20}

De estar los desposados juntos mucho tiempo sin recibir las bendiciones de nuestra santa madre Iglesia no se sirve Dios nuestro señor, especialmente que muchos no solamente se están así juntos poco tiempo pero algunos se están más tiempo de tres o cuatro años, y pues es justo que luego que los tales por palabras sean desposados cumplan lo determinado por nuestra santa madre Iglesia y reciban las bendiciones de ella para se estar más en servicio de Dios nuestro señor, S. A. S. ordenamos y mandamos que todo fiel cristiano que se casare en este nuestro Obispado por palabras, se presente dentro de 30 días después que fuere desposado, se vele y reciba las bendiciones de nuestra santa madre Iglesia, so pena de descomunión y de 10 pesos de oro de minas aplicados a la fábrica de esta santa iglesia y cera del santísimo sacramento y acusador por tercias partes, lo cual haya lugar en los españoles, mestizos y mulatos y negros. Y

Estudios de Cultura Maya. Vol. XXIV, 2003

Instituto de Investigaciones Filológicas/

Centro de Estudios Mayas, UNAM

ISSN 0185-2574 
entre los naturales encargamos a nuestros rectores [que] luego que desposaren los tales naturales indios les solemnicen las bodas y les bendigan.

\section{Constitución 21}

Y porque en el santo Concilio Tridentino está determinado que todos los que se quisieren casar sean primeramente amonestados tres veces en tres fiestas, y entre estos naturales nuestros ministros, en las visitas que tienen a cargo, no pueden visitallos tan a menudo que las dichas tres vanas se hagan sucesivamente, y si se diese lugar que se hubiesen de hacer en tres días de fiesta, por no poder ir a los visitar a menudo, se podían pasar muchos días en los cuales - por la poca constancia de los indios- no vendrían a efecto los dichos matrimonios y muchos los consumarían antes de ser desposados, lo cual se debe evitar, por ende, atentas las dichas razones, S. A. S. ordenamos y mandamos y permitimos a los dichos nuestros curas y rectores en sus visitas solamente en una fiesta o el día que fueren a visitar algún pueblo de su visita donde se haya de contraer algún matrimonio, hagan las dichas tres amonestaciones en el dicho día o fiesta, e inquieran con toda diligencia si haya algún impedimento entre los contrayentes, y no lo habiendo los casen como si en tres fiestas hubieran hecho las dichas tres amonestaciones, lo que se entienda si en el dicho pueblo no hubiere de estar más de un día. Y si estuvieren tres, harán las dichas tres vanas.

\section{Constitución 22}

Y porque en señal de matrimonio en Derecho Canónico se dan las arras entre los esposo y esposa y así se guarda por costumbre muy antigua en nuestra santa madre Iglesia que los tales contrayentes, para solemnizar las bodas y recibir las bendiciones en señal de matrimonio que se contrae, lleven 13 monedas y en muchas partes de este nuestro Obispado entre [f 10 ] los naturales se usa llevar estas monedas - en unas partes de más valor que en otras y en algunas no de su voluntad por ser compelidos con $\mathrm{m} / \mathrm{u}$ ]chas imposiciones-S. A. S. ordenamos y mandamos de aquí adelante los tales naturales y todos los que recibieren las bendiciones de nuestra santa madre Iglesia lleven tres monedas, y éstas, las que ellos quisieren. Y si alguno de nuestros curas — por vía directa e indirecta, por sí y por interpósitas personas- compelieren a los dichos naturales que estas monedas las lleven de más valor de que ellos quisieren que suelen llevar de su voluntad, incurran en pena por la primera vez de 30 pesos de oro de minas aplicados la tercera parte para nuestra Cámara y la otra tercera parte para el acusador y la otra tercera para el juez que lo sentenciare, y por la segunda doblado y será castigado a nuestro arbitrio.

\section{Constitución 23}

Ítem, porque aún a estos naturales le dirán algunas cosas de sus antigüedades y supersticiones [en] especial en los matrimonios, los cuales los padres y parientes hacen casar 
a sus hijas y parientas con algunos indios y le compelen a que presten su consentimiento y esto por precio que les dan los indios que con ellas quieren contraer matrimonio - que entre ellos se llama vender las mujeres- de lo cual nace que los tales indios como no dan su consentimiento de voluntad después contradicen los tales matrimonios y hay entre ellos tales casados escándalos y [p]leitos de que Dios nuestro señor es deservido, para que cesen los dichos ordenamos y mandamos S. A. S. a cada cura y vicario [que] en su Partido y visita tenga especial cuidado de se informar al tiempo que los tales indios e indias vienen ante él para se casar, si la tal india indio o alguno de ellos viene compelido por sus padres o parientes a hacer el tal matrimonio, o si los dichos sus padres o parientes han vendido a tal india por algún precio al que con ella quiere contraer, como entre ellos se dice, y siendo así no dará lugar al dicho matrimonio ni casará a los dichos indios que en esta forma y por precio que entre ellos hay se vinieren a casar, sino fuere constándole venir libremente y con toda voluntad querer hacer el dicho matrimonio, amonestándoles y dándoles a entender cómo de pura y libre voluntad deben prestar el dicho consentimiento; reprendiendo y castigando a los dichos naturales las dichas supersticiones que de sus antigüedades tienen. Lo cual guarden los dichos curas so pena de ser castigados a nuestro arbitrio y lo rogamos y encargamos a los religiosos.

\section{Constitución 24}

Otrosí somos informados que muchos clérigos en la vista y Partido de otros, y los religiosos de las órdenes, unos en las visitas de otros y otros de otros, donde con nuestra licencia y beneplácito tienen la administración de los santos sacramentos, se entrometen y administran los santos sacramentos, especialmente casando algunos indios o indias que no son sus feligreses ni de su visita, lo cual es gran inconveniente y tanto conforme al santo Concilio Tridentino tal matrimonio, por no ser hecho por su cura propio de los tales contrayentes, es ninguno, y para excusar y evitar lo dicho S. A. S. ordenamos y mandamos que ningún clérigo ni religioso de las [f $10 \mathrm{v}$ ] órdenes, uno en la visita del otro, ni otro en la de otro, se entremetan en administrar ni administren ninguno de los santos sacramentos sino fuere a ruego y con voluntad y beneplácito de tal cura y rector del dicho Partido y visita. Lo cual guarden y cumplan los dichos nuestros curas y vicarios so pena que serán por nos o por nuestro provisor gravemente castigados. Lo cual encargamos y rogamos a los religiosos así lo guarden y cumplan, con apercibimiento que desde agora para entonces luego que cualquiera de ellos traspasare esta nuestra sinodal, por el propio hecho es nuestra voluntad se le quite y quitamos nuestro beneplácito y voluntad que para administrar los santísimos sacramentos tiene, demás que encargamos a sus prelados al trasgresor de esta nuestra sinodal, demás de lo dicho, lo castiguen.

\section{Constitución 25}

Y porque en el santo sacramento del bautismo asimismo está determinado lo que se debe llevar y en algunas partes de este nuestro Obispado han impuesto a los naturales 
que lleven más de lo necesario, y en otras no llevan lo necesario para se les administrar las ceremonias que nuestra santa madre Iglesia manda en el bautismo, por ende S. A. S. ordenamos y mandamos que cuando los fieles cristianos llevaren a bautizar cualquier criatura lleven lo necesario, que es una candela, cual les pareciere, y en ella la limosna que quisieren o pudieren para el sacerdote, y su capillo de lienzo blanco, que es significación de la limpieza y castidad que prometen de guardar los tales bautizados en la fe de Jesucristo.

$\mathrm{Y}$ mandamos a nuestros curas y vicarios no excedan de lo susodicho ni pongan costumbre en les pedir ni llevar por fuerza más ni menos de lo declarado, lo cual les digan y declaren ser obligados a ello. Lo cual los dichos nuestros curas guarden y cumplan so pena de ser gravemente castigados lo contrario haciendo.

\section{Constitución 26}

Por Derecho Canónico está determinado que con todo cuidado y en lugar decente y su fideli [sic] custodia esté el santo crisma y óleo, y para que así se cumpla y en esto no haya falta, S. A. S. ordenamos y mandamos que todos los curas y vicarios de este nuestro Obispado tengan en todas las iglesias de sus partidos sus crismeras y caja con sus llaves, donde estén con toda limpieza. Y porque de no las haber en cada pueblo y de las llevar de un pueblo en otro al tiempo que los visitan no se pueden tener el cuidado que es razón, por las haber de fiar de algún natural que las lleve y por el peligro que puede haber de se derramar el santo crisma y óleo y no ser casa decente, para que lo susodicho cese, pues a tan poca costa se puede hacer, ordenamos y mandamos que así se guarde y cumpla y que todos [los] curas, en cada pueblo de su Partido y visita, hagan la dicha cajuela con sus llaves y sus crismeras de plata, y si no hubiere la posibilidad sean de estaño. Y en una parte de la iglesia, donde más cómodo le pareciere, hagan en la pared una alacena con su llave donde esté la dicha cajuela guardada y no fie la lleve [sic por llave] de ningún natural [f 11], para que de esta manera cese el inconveniente e [in]decencia de traer el santo óleo y crisma de un pueblo en otro y el peligro que hay en derramarse. Lo cual encargamos a nuestros curas y vicarios hagan y cumplan so pena de ser castigados a nuestro arbitrio si en ello tuvieren descuido. Y lo propio rogamos y encargamos a los religiosos que tienen a cargo la doctrina entre los naturales de este nuestro Obispado.

\section{Constitución 27}

Por el santo Concilio Tridentino está determinado que ninguno sea promovido ad sub diaconatus ordinem ante vigesimum secundum su eltatis [sic] anum et a diaconatus ante vigesimuiim tertium anim et at presbiteratum ante vijesimum [sic] quintum anim, demás de lo cual asimismo debe traer probanza de su vida y costumbres y linaje. Y para que así sea guardado, S. A. S. ordenamos y mandamos que cualquier persona de cualquier dignidad y calidad que sea, aunque sea regular de este nuestro Obispado que viniere para que le ordenemos, traiga información de su vida y costumbres y linaje. Y si no fuere 
regular, demás de lo dicho, si no tuviere beneficio a cuyo título deba ser ordenado, traiga a lo menos 500 pesos de patrimonio, y de otra manera no será por nos a ninguna de las dichas órdenes promovido.

\section{Constitución 28}

Por Derecho Canónico está establecido y ordenado como cosa muy importante y necesaria para el buen ejemplo que deben dar los ministros de Dios y la honestidad y decencia que deben tener en su hábito, y aun por sinodales pasadas, conforme a Derecho, se ha prohibido a los dichos clérigos y dado orden en qué manera deben vestir. Y porque [en] la sinodal hecha por nuestro antecesor justamente [l]es está ordenado, mandamos que aquella sea guarda[da] y cumplida, y solamente innovamos en la dicha constitución que los que no fueren sacerdotes no puedan traer en los manteos y otras ropas, vueltas de terciopelo ni raso, ni becas, ni que los que fueren sacerdotes puedan andar ni anden a caballo paseando por las ciudades, villas ni lugares de este nuestro Obispado. ${ }^{57} \mathrm{Y}$ en cuanto a esto enmendamos y revocamos la dicha sinodal, y en lo demás queremos sea guardada y cumplida so la pena en ella contenida.

\section{Constitución 29}

Otrosí, no solamente deben los ministros de Dios dar en su manera de vivir y vestir buen ejemplo a los españoles, pero principalmente por su parte se debe tener cuenta con que los naturales de estas partes, nuevamente convertidos a nuestra santa fe, no solamente sean doctrinados predicándoles la ley de Dios con palabras de palabra [sic] pero se debe hacer principalmente con obras, que es verdadera predicación que es lo que más a los dichos aprovecha. Por ende ordenamos y mandamos que los curas y vicarios de este nuestro Obispado y religiosos que a cargo tienen la administración de los naturales vivan honestamente en su hablar y conversar, comer, beber y vestir, de manera que los dichos naturales reciban buen ejemplo.

$Y$ porque de no andar los dichos nuestros curas y vicarios entre los naturales vestidos con ropas largas y no de colores pertenecientes a sacerdotes, y de andar en cuerpo, se causa mal ejemplo, mandamos a los dichos nuestros curas [f $11 \mathrm{v}$ ] y vicarios entre los dichos naturales guarden la decencia conveniente al sacerdocio, teniendo ropas largas hasta abajo, no trayendo calzas acuchilladas con rasos, ni terciopelos negros ni de colores. Lo cual guarden y cumplan so pena por la primera vez de 10 pesos, y la ro-pa perdida, aplicando la ropa para el acusador y [de] los 10 pesos la mitad para gastos de la iglesia donde fuese cura y la otra mitad para el juez que lo sentenciare, y por la segunda la pena doblada y la ropa perdida según dicho es, y por la tercera, privación de beneficio.

\footnotetext{
${ }^{57}$ Las disposiciones de Marroquín al respecto apuntaban: "que cualquier clérigo de prima tonsura [... use de vestidos honestos, conviene a saber: loba, capa o manteo cerrado o abierto, y largo hasta la tierra, que no sea de color encarnado ni amarillo, sino honesto, y lo mismo se entiende del vestido interior" (apud Remesal, 1966: 340).
} 
Y porque de tener los clérigos y curas que están administrando los naturales, a la contina por huéspedes a los españoles tratantes en sus casas, y de la mucha conversación que con ellos tienen, causa menosprecio y venir a ser tenidos en poco y menospreciados, para que lo dicho cese, y no les impidan administrar los dichos santísimos sacramentos, S. A. S. ordenamos y mandamos que todos los clérigos y curas que están en los partidos de los naturales no reciban ni tengan en sus casas huéspedes a la contina, si no fuese a sus hermanos parientes. Solamente permitimos, porque nuestra intención no es prohibir la caridad que los tales clérigos [muestran] a los que de camino pasan por los dichos partidos, les puedan hospedar tres días y no más. Lo cual guarden y cumplan so pena de 30 pesos la primera vez, atento que somos informados que de lo recibir y tener a la contina se causa gran menosprecio del sacerdocio, y por la segunda vez la pena doblada y será removido de tal administración; la mitad para el acusador y la otra mitad para el juez que lo sentenciare.

\section{Constitución 31}

Porque conforme a derecho los sacerdotes ministros de Dios siempre se deben ocupar en ejercicios santos y buenos procurando saber lo tocante perteneciente al oficio y dignidad que tienen para que siendo preguntados por los fieles puedan satisfacerlos mostrándoles la ley de Dios que los tales son obligados saber, según está dicho por el profeta Malaquías capítulo segundo Labia sacerdis custodium et sientiam et exore eius lesen requirmut para que en lo dicho de parte de los dichos ministros de Dios no haya descuido y sepan lo que les conviene como a tales, les mandamos y rogamos se ejerciten en estudiar para saber lo que así les conviene y para ello les mandamos tengan y compren algunos libros perteneciente a su oficio. A lo menos tengan la Biblia y algún sermonario y el manual de Navarro o la Suma Gayetana o Silvestrina, los cuales dichos libros tendrán, so pena que al que fuere hallado al tiempo de su visita sin algunos de los dichos libros será castigado a nuestro arbitrio y de nuestro provisor, como descuidado y negligente en su oficio.

\section{Constitución 32}

Los sacerdotes ministros de Dios dedicados al servicio de Dios ajenos deben ser de toda codicia; deben procurar ser a Dios agradables en el [f 12] oficio que tienen; solamente se deben contentar con lo que justamente de sus ofrendas les viene conforme a lo [que] por Derecho Canónico está establecido en el capítulo Qui altario de prevendis dinitatibus $y$ etc. Y porque solamente se deben contentar con lo dicho y no tener tratos ni contratos, S. A. S. estatuimos y ordenamos que ningún clérigo de ningún estado y dignidad que sea en este nuestro Obispado trate ni contrate indios ni españoles, comprando para comprar y vender, por sí ni por interpósitas ni por terceras personas, ni rescate cacao de los naturales, ora sean de su partido, ora de otro cualquiera. Y el di- 
cho rescate no sea en poca o en mucha cantidad porque nuestra intención es, aunque le era permitido el rescate [de] hasta 12 cargas de cacao, atento que era ocasión para rescatar mucha cantidad y para que abajo de aquella permisión los naturales recibiesen mal en ejemplo, S. A. S. prohibimos y mandamos, innovando la sinodal pasada hecha por nuestro antecesor de buena memoria, que de aquí adelante, en poca ni en mucha cantidad ninguno rescate cacao entre los dichos naturales ni otras mercadurías, y en lo demás que no es contraria a esta nuestra sinodal queremos sea guardada y cumplida según y como por ella está determinado. ${ }^{58} \mathrm{Y}$ esta nuestra sinodal la guardarán so pena que por la primera vez que contra ella fueren incurran en 50 pesos de oro de minas de pena y por la segunda 100 y por la tercera la pena doblada y destierro de este nuestro Obispado, las dichas penas aplicadas por tercias partes para nuestra Cámara, juez que lo sentenciare y denunciador.

\section{Constitución 33}

Y porque el provecho que los naturales dan a nuestros curas y rectores es ofrecerles ropa y cacao y otras cosas que consisten en los frutos de la tierra, lo cual necesariamente los dichos nuestros curas han de vender para se aprovechar de ello, comprando otras cosas de que ellos tienen necesidad, permitimos que las tales ofrendas las vendan a españoles tratantes entre los dichos indios para que en todo cese el mal en ejemplo que en alguna manera los naturales pueden recibir de ver que el clérigo las vende, y si no hallan español que se las compre, permitimos que las pueda beneficiar por el pueblo sin escándalo.

\section{Constitución 34}

Cosa clara es que estos naturales usan del vino según vemos y es notorio hacen ofensa a Dios nuestro señor a quien todos debemos servir de todo corazón, procurando y evitando no se hagan ofensas a su divina majestad y porque algunos tratantes entre los naturales propuesto [sic por pospuesto] el temor de Dios nuestro señor, en menosprecio de sus conciencias, dan ocasión de ser ofendida la divina majestad con grandes borracheras que causan vendiéndoles vino a los naturales, de las cuales Dios nuestro señor es mortalmente ofendido así por los indios borrachos como [por] los que les venden el vino, pues dan causa a ello, y porque a los clérigos, por la sinodal pasada de nuestro antecesor de buena memoria le está prohi[f $12 \mathrm{v}]$ bida la dicha venta so pena de descomunión mayor y por ispo lipsol facto, conformándonos con el santo Concilio Tridentino y por evitar que la dicha descomunión, siendo medicinal, no cause pestilencia, innovando la dicha sinodal, S. A. S. ordenamos y mandamos que ninguna persona clérigo ni lego de ningún estado ni dignidad que sea no venda vino a los dichos naturales por sí ni por interpósitas personas, ni se lo dé en ninguna manera por vía de intereses, lo cual cumplan so pena por 25 pesos la primera vez, aplicados la tercia parte para el acu-

${ }^{58}$ Ver nota 37. 
sador y la tercia para gastos de la iglesia del pueblo donde se vendiere y la otra tercia para el juez que lo sentenciare, y por la segunda vez si fuere clérigo el que vendiere o hiciere vender el dicho vino, sea desterrado perpetuamente de nuestro Obispado, y si fuere lego sea la pena pecuniaria doblada. Y atento que Dios nuestro señor, de les vender el dicho vino a los naturales es ofendido mortalmente, así por el escándalo como por la maldad del dicho [¿vino?] y ofensa, hacemos el dicho caso a nos reservado; reservamos la absolución del dicho pecado a nos o nuestro provisor, y mandamos, so la dicha pena, a nuestros curas y vicarios no absuelvan a los dichos que hubieren vendido vino a los dichos naturales sin nuestra especial licencia y del dicho nuestro provisor.

\section{Constitución 35}

Porque de tener algunos clérigos de este nuestro Obispado negros y negras en la Villa de la Trinidad y otras partes en pueblos de los naturales, al trato del rescate y a ganar, se da grande escándalo y recibe mal ejemplo de los dichos nuestros clérigos y en efecto se entiende tratar los dichos clérigos por aquella vía, demás que se entiende los dichos negros, por cumplir con los dichos sus amos clérigos, hacen algunos agravios y maltratamientos a los naturales y ofensas a Dios nuestro señor, a lo cual no solamente [no] deben ser ocasión los ministros de Dios, mas por todas vías lo deben evitar, ayudando y favoreciendo a los naturales para que no sean molestados, S. A. S. ordenamos y mandamos que de aquí adelante dentro de 30 días después de la publicación de este sínodo, ningún clérigo de ningún estado ni calidad que sea de este nuestro Obispado no tenga negro ni negra al dicho trato de rescate ni a ganar, so pena de 40 pesos por la primera vez y por la segunda doblada la pena y por la tercia destierro de este nuestro Obispado, aplicada la dicha pena por tercias partes para la nuestra Cámara, juez que lo sentenciare y denunciador.

\section{Constitución 36}

Porque nuestra intención principal es que estos naturales nuevamente venidos a la fe de Jesucristo siempre aprovechen, y a cada día más, en sus costumbres y en servir a Dios nuestro señor, para lo cual es principal causa que nuestros ministros entre ellos les den buen ejemplo, mostrándoles principalmente y dándoles a entender ser su principal intento de les doctrinar, no mostrándoles codicia ninguna. Y debiendo hacer lo dicho somos informados que en algunas partes de este nuestro Obispado se les da mal [f 13] ejemplo y molestia a los naturales por nuestros ministros, comprándoles deudas que los dichos naturales deben a algunos españoles tratantes entre ellos, por las cobrar los dichos clérigos de los dichos indios. Y porque es común práctica entre los dichos tratantes vender su ropa a los naturales a subido precio, fiada con intención, y porque saben que después les han de comprar los clérigos las tales ditas ${ }^{59}$ para las cobrar para

\footnotetext{
${ }^{59}$ Deudas.
} 
sí de los dichos indios, en lo que se les hace molestia y agravio a los dichos naturales por cobrar de ellos las dichas deudas que los dichos naturales no son obligados a pagar a los dichos españoles, por estar prohibido por real provisión en este Obispado ningún lego trate con indio ni le fie, so pena de perder la dicha deuda.

$\mathrm{Y}$ que por efecto de estos trueques y tratos resulta comprar nuestros clérigos para ganar, [lo] que por Derecho les está prohibido, y de ello resulta escándalo que pretendemos evitar, S. A. S. ordenamos y mandamos que ningún clérigo, ni vicario, ni cura de este nuestro Obispado sea osado de comprar ni feriar ditas que los dichos naturales deban a ningún español para las cobrar él de los dichos naturales por sí ni por otra persona direte ni indirete, so pena que el que lo contrario hiciere por la primera vez pierda las ditas que así comprare y los dichos indios no se las paguen, y más incurra en pena de 20 pesos de oro la mitad para el acusador y la otra mitad para el juez que lo sentenciare, y por la segunda en 50 pesos aplicados según dichas y las ditas perdidas y privación de beneficio. Y si las dichas ditas las tuviere cobradas al tiempo que fuere visitado, sea la dicha pena 60 pesos y privación de beneficio.

\section{Constitución 37}

Otrosí, porque en algunas iglesias los vecinos y naturales de este nuestro Obispado necesariamente para el culto divino han de comprar algunos ornamentos, cruces y cálices y otras cosas necesarias, y en algunas partes por no estar hechas las iglesias o por estar mal hechas conviene las unas se hagan y las mal hechas se reparen, y asimismo conviene en algunas partes se hagan casas para nuestros curas y vicarios, y todo esto es razón se haga con nuestra licencia y dándonos aviso de ello, S. A. S. ordenamos y mandamos que de aquí adelante ninguno de nuestros curas ni vicarios ni religiosos que a cargo tienen la administración de los naturales no compren ornamentos, cruz ni cáliz ni incensarios, ni haga iglesia ni casa para sí sin nos dar aviso de la necesidad que los dichos naturales tienen, para que nos demos orden - la que se debe dar- para que lo dicho se haga y los dichos ornamentos y lo que fuere necesario se compre. Lo cual cumplan y guarden los dichos nuestros curas y vicarios so pena de 50 pesos de oro de minas, la tercia parte para nuestra Cámara, la tercia para el juez que lo sentenciare, la tercera para el acusador. Y [a] los religiosos que tienen a cargo algunos pueblos de los naturales de este nuestro Obispado le encargamos y rogamos que así lo guarden y cumplan porque es nuestra voluntad; con apercibimiento de [que] lo contrario haciendo se le quitará nuestro beneplácito desde luego.

\section{Constitución 38}

Otrosí, S. A. S. ordenamos y mandamos que ningún clérigo nuestro, cura ni vicario en este Obispado cargue a indio ninguno con ninguna ropa ni otra cosa. Solamente permitimos que cuando los dichos nuestros curas fueren a visitar de unos pueblos a otros, que los indios del un pueblo lleven al pueblo donde fuere [a] visitar, su cama y libros y un chicobite [chiquihuite o canasto], pues es justo que yéndoles [a] administrar los santísimos 
sacramentos y a les mostrar la doctrina cristiana les ayuden en esto. Y fuera de lo dicho ninguno sea osado de cargar los dichos indios fuera de la ordenanza y cuando lo permite el rey nuestro señor, so pena que el que lo contrario hiciere incurra en pena por la primera vez en cinco pesos y por la segunda 10 pesos, demás de pagar [a] los dichos indios que así cargaren su trabajo, aplicados a la mitad para el juez que lo sentenciare y la mitad para el acusador, y por la tercera, pena doblada, aplicados en la dicha forma.

\section{Constitución 39}

Y porque conforme al santo evangelio, la doctrina de Jesucristo no se debe mostrar con castigo corporal, antes muy amorosamente, dando a entender a estos naturales el bien que pierden en ser malos cristianos y no servir a Dios nuestro señor como le deben servir y amar de puro corazón y voluntad, atrayéndolos al servicio y amor de Dios con todo amor y palabras amorosas y no con azotes, S. A. S. ordenamos que ninguno de nuestros curas ni vicario azote a los dichos naturales ni los mande azotar en ninguna manera, por razón que no saben ni deprenden [aprenden] la doctrina.

Permitimos que si alguno de los naturales cometiere algún delito como blasfemias, amancebamientos, hechicerías y supersticiones, los puedan castigar y proceder contra ellos breve y sumariamente, castigándoles conforme a la calidad del delito. Y si otros delitos cometieren otras cualesquier personas de cualquier estado y calidad que sean, cometieren cualquier delito tocante el [sic] conocimiento de la nuestra jurisdicción, hecha la información nos lo remitiréis para que se provea en ello justicia.

Y si alguno de los dichos naturales fueren tan descuidado que no aprendiere la doctrina de Jesucristo o no bastare ser atraído con buenas razones, este tal —pues está obligado por haber recibido el santo bautismo a la saber- permitimos que vos, los dichos nuestros curas y vicarios, con los tales haya[is] algún castigo moderado, pues si en todo se hubiese de dejar a la voluntad de los dichos naturales entendemos aprovecharían muy poco en las cosas de nuestra santa fe católica. Lo cual encargamos así sea guardado y cumplido so pena de ser castigados los transgresores a nuestro arbitrio.

\section{Constitución 40}

Cosa clara es que si a que estos naturales en alguna manera no fuesen apremiados por nuestros curas y vicarios aprovecharían muy poco en las cosas de nuestra santa fe católica, por lo cual como cosa conveniente S. A. S. ordenamos y mandamos que de aquí adelante cada cura y vicario en su Partido tenga especial cuidado que todos los indios e indias [ $\mathrm{f} 14$ ] cada fiesta vengan a la misa mayor y el que faltare, si no diere causa justa que le excuse el no haber podido venir, mandamos que el tal cura, públicamente, en la fiesta que se siguiere, delante de todo el pueblo le reprenda de palabra. $Y$ permitimos que el tal cura le pueda penar en una penilla moderada según y como se hace en los reinos de Granada con los moriscos, y la dicha pena sea para [la] iglesia y para lo necesario a ella. De las cuales [penas] los dichos curas tendrán cuenta y razón. 
Y para que lo dicho tenga efecto, cada uno de los dichos curas tendrá padrón de los dichos sus feligreses para que por él vea los que faltan y aquellos sean castigados. Lo cual sea guardado y cumplido so pena que cualquiera de los dichos nuestros curas que no tuviere el dicho padrón y cuenta sea castigado por la primera vez en cinco pesos de oro y por la segunda 10 , aplicados para el juez que lo sentenciare y denunciador, y por la tercera, además de la pena, sean castigados a nuestro arbitrio.

\section{Constitución 41}

El declarar el santo evangelio sólo es nuestro oficio y a nos pertenece y a los que nuestro poder tuvieren, y no lo deben de hacer personas legas a quien por derecho les está vedada la predicación. Y porque algunas personas legas en este nuestro Obispado, sin tener suficiencia ni habilidad, ni ser su oficio, en las iglesias y fuera de ellas hacen juntar a los naturales y les predican y dicen cosas de nuestra santa fe, de lo que no estamos satisfechos pueda suceder bien ninguno, pues para el poder predicar a estas gentes tan nuevas debe hacer con mucha curiosidad y buscar causa y maña para les dar a entender nuestra santa fe, especialmente que debajo de forma de predicación les dicen otras cosas profanas que a los dichos les conviene, y no se sufre que en la iglesia, casa de oración, se trate otra cosa que predicarles nuestra santa fe, y esto por nos o por nuestros ministros conforme al santo Concilio Tridentino, sesión 24, capítulo 4, por ende, S. A. S. ordenamos y mandamos que ninguna persona de ningún estado ni calidad que sea, en las iglesias y fuera de ellas, predique a los dichos naturales, so pena de descomunión mayor en la cual incurra ispo [ipso] facto lo contrario haciendo; la absolución de ello a nos reservada o nuestro provisor, y más en pena de 20 pesos aplicados para los gastos de las iglesias donde el dicho hiciere la dicha predicación. Y no es nuestra intención de evitar que las tales personas legas dejen de amonestar y reprender a los dichos naturales, con la corrección fraterna, los pecados y ofensas que contra Dios nuestro señor les vieren hacer.

\section{Constitución 42}

Otrosí ordenamos y mandamos que al tiempo que el sacerdote saliere a ofrecer, se esté al pie del altar o en la primera grada de las escaleras en que suben al altar, para que los hombres que quisieren lleguen a ofrecer y para que las mujeres asimismo lo hagan, salga a la puerta de la capilla y se esté quedo y no ande por el cuerpo de la iglesia entre las mujeres. Lo cual cumplan y guarden todos nuestros curas y vicarios, pues es cosa decente y conveniente no hacer lo contrario, so pena de ser castigados a nuestro arbitrio.

\section{[f 14v] Constitución 43}

Y porque en este nuestro Obispado somos informados que en muchas partes de él, en las iglesias los naturales, y en sus casas, tienen algunas imágenes de santos y santas y 
crucifijos pintados de manos de indios, las cuales en sus pinturas están mal dibujadas, que antes provocan a menosprecio y risa y no a devoción, por ende, S. A. S. ordenamos y mandamos que nuestros curas y vicarios que en los dichos sus partidos tengan especial cuidado de recoger las dichas imágenes que así hallaren mal dibujadas y se las quiten así de sus casas como de las iglesias donde estuvieren, dándoles a entender la causa y razón porque se hace, lo cual encargamos a los religiosos que están en este Obispado. Y porque algunos las tienen en partes no decentes sobre la candela, donde se ahuman, se les avise los tengan en lo mejor de su casa y cubiertas con la reverencia $y$ decencia que conviene.

\section{Constitución 44}

En este nuestro Obispado somos informados que hay muchos hombres casados en otras partes, ausentes mucho tiempo de sus mujeres, los cuales están en mal estado y de ello se desirve nuestro señor. $Y$ aunque su majestad tiene proveído cerca de los dichos para que sus justicias los hagan ir a hacer vida maridable con sus mujeres, todavía no cesan de andar en este nuestro Obispado muchos casados ausentes de sus mujeres. Para que mejor se cumpla y guarde lo que su majestad tiene mandado, pues es servicio de Dios nuestro señor, S. A. S. mandamos a nuestros curas y vicarios que a los penitentes que confesaren siendo casados en otras partes, como haya dos años que estén ausentes de sus mujeres no les absuelvan, porque por la presente hacemos reservado a nos este caso. Lo cual encargamos a todos los religiosos de las órdenes.

\section{Constitución 45}

Y aunque por Derecho Canónico son muchos los casos a nos reservados, usando de piedad con los penitentes y de gracia con nuestros curas y rectores, aun ${ }^{60}$ clérigos como religiosos, que con nuestro beneplácito tuvieren la administración de los santísimos sacramentos, les cometemos todos nuestros casos por agora y hasta que sea nuestra voluntad, para que en ellos puedan poner las penitencias que les pareciere ser saludables; solamente reservamos para nos y para nuestro provisor los contenidos en el sínodo hecho por nuestro antecesor de buena memoria, y las excomuniones y casos reservados en estas nuestras sinodales, que son los siguientes:

La descomunión en la que incurre el que predica a los naturales.

El que no confesare la Cuaresma y hasta cuando está declarado.

El pecado del que vendiere vino a los naturales.

Los que no se velaren dentro de 30 días después de que se desposaren.

De los casados en los reinos de España y otras partes.

Homicidio voluntario.

${ }^{60}$ Empleado con el sentido de "tanto". 
Aborsus voluntario entre españoles.

[f 15] Diezmos no pagados.

Cualquier herejía.

Incendiarios.

Poner manos violentas en clérigo o religiosos.

Amancebados públicos entre españoles.

Tomar cartas mensivas.

Incestos dentro del cuarto grado entre españoles.

Sacrilegio.

Acceso carnal entre compadres.

Y más todos los que por esta sinodal constare estar reservados.

\section{Constitución 46}

Otrosí, por Derecho Canónico a ningún clérigo ni religioso sacerdote se debe permitir celebrar sin traer letras de sus prelados, y por este nuestro Obispado suelen pasar algunos religiosos y clérigos de otras partes, a los cuales por la dicha razón no se debe permitir celebrar. Por ende, para que lo dicho sea guardado y cumplido, S. A. S. ordenamos y mandamos a todos nuestros curas y vicarios que en este nuestro Obispado a ningún clérigo ni religioso que no sea conocido en sus partidos no consienta ni dejen celebrar ni den recaudo para ello si no trajere letras dimisorias de sus perlados, auténticas, o llevaren nuestras licencias o de nuestro provisor. Lo cual cumplan y guarden so pena de ser castigados a nuestro arbitrio.

\section{Constitución 47}

Otrosí por cuanto su santidad ha concedido a los españoles y naturales que están en estas partes de la Nueva España siete breves, y éstos conviene que se publiquen para que venga a noticia de todos, así españoles como naturales, S. A. S. ordenamos y mandamos que de aquí en adelante cada cura en su Partido y curato dé a entender los dichos naturales y españoles los dichos breves de su santidad. Y para que lo contenido en ello los dichos naturales lo sepan y los demás y nuestros ministros se los puedan predicar, declaramos lo que en dichos breves se contiene, que es lo siguiente:

Primeramente para que los naturales puedan recibir las bendiciones municiales [sic por nupciales| en todo tiempo divino.

Ítem, que en tiempo de entredicho, aunque sea apostólico, los naturales puedan en sus iglesias y en otros lugares oír misa estando las puertas de la iglesia abiertas y puedan hacer tañer campanas y celebrar los divinos oficios, excluidos los entredichos y descomulgados, y les puedan administrar todos los santísimos sacramentos y enterrarlos en sagrado, con tanto que no hayan dado causa a tal entredicho.

Ítem, en otro breve concede su santidad a los dichos, que todas las veces que en estas partes su santidad concediere algún jubileo o indulgencia plenaria para que lo ganen los que hubieren confesado y ayunado y hecho lo demás que su santidad mandare, 
y los dichos naturales lo puedan ganar y ganen teniendo contrición de sus pecados y propósito de se con[f 15v]fesar cuando tuvieren copia de confesor, [0] a lo menos teniendo propósito de se confesar y ayunado y haciendo lo demás.

İtem, [por] otro breve concede su santidad que los arzobispos y obispos puedan consagrar con bálsamo de estas partes el santo crisma y óleo de los enfermos y ente cominorum con el número de los ministros que cómodamente se pudieren haber.

Ítem, en otro breve se contiene que puedan comer lardo, queso y leche y todo género de manteca en Cuaresma y tiempos vedados, así españoles como indios, por 30 años.

Ítem, en otro breve se contiene que los perlados, arzobispos y obispos de Indias no sean obligados a ir a visitar por sus personas limina apostolorum Petri et Pauli, con [tal] que envíen en su lugar procurador para lo susodicho cada cinco años.

ítem, en otro breve se trata sobre los religiosos que van a Castilla.

\section{Constitución 48}

Otrosí somos informados que muchas personas legas, especialmente los que son nombrados para hacer algunas cuentas y padrones de estos naturales para ser tasados en los tributos que han de dar a sus encomenderos, a campana tañida hacen juntar el pueblo en la iglesia, y ahí dentro hacen la dicha cuenta y padrón, causa mere profana de que se sigue gran escándalo y que no se sufre hacer en la casa de Dios, lugar no para semejantes negocios.

Y pues estos naturales van aprovechando en toda policía y entienden cualquier cosa y se escandalizan de lo mal hecho, es mucha razón dalles a entender que la iglesia, casa de Dios, es solamente para donde su santo nombre sea alabado y para que en ella no se hagan ni traten negocios profanos, ordenamos y mandamos a todos nuestros curas y vicarios y rectores de los naturales no consientan ni permitan que en las iglesias los dichos contadores hagan la dicha junta ni tañan las campanas para juntar al dicho pueblo para el dicho efecto, pues aquello no les es mandado por los gobernadores ni es razón que [en] la dicha iglesia, casa de Dios, se haga. Lo cual harán guardar y cumplir los dichos nuestros curas a los que con atrevimiento quisieren traspasar esta nuestra sinodal, profanando la iglesia de Dios, procediendo contra ellos hasta los descomulgar hasta descomunión mayor, guardando la forma de derecho.

\section{Constitución 49}

Otrosí porque hemos proveído que en esta nuestra santa iglesia todos los domingos y fiestas de guardar se enseñe la doctrina cristiana a los negros y a todo servicio, encargamos y rogamos y mandamos en virtud de santa obediencia todos los fieles envíen su servicio todos los domingos y fiestas de guardar a la dicha iglesia.

Otrosí dejamos abierto este dicho sínodo para añadir lo que conviniere [f 16] más al servicio de Dios nuestro señor y para que cumplidamente sea proveído a lo tocante en buen gobierno de este nuestro Obispado. 


\section{Constitución 50}

Otrosí, S. A. S. mandamos que estas nuestras constituciones sinodales sean guardadas y cumplidas y se guarden y cumplan por todos nuestros curas y vicarios y ciérigos y fieles vecinos y moradores estantes y habitantes en este nuestro Obispado, según y como en ellas se contiene, y no es nuestra intención de en todo ni en parte derogar lo establecido y ordenado y determinado por el Derecho Canónico, solamente derogamos las constituciones sinodales de este nuestro Obispado, en ${ }^{61}$ aquello en lo que son contrarias a estas nuestras.

Y para que este dicho sínodo sea guardado y cumplido, y seamos avisados de los que no guardan y cumplen este santo sínodo y de los demás que contra nuestra santa fe católica en dicho o en hecho viven mal, nombramos por testigos sinodales -para que nos dé aviso de las ofensas que contra Dios nuestro señor fueren hechas- al que es o fuere nuestro cura y vicario en el pueblo de Naolingo y al que es o fuere en la ciudad de San Salvador y el que es o fuere en la villa de San Miguel y al que es o fuere en Guacazapán, $y$ al que es o fuere en los pueblos de Suchitepéquez, y al que es o fuere en el pueblo de Hue[h]uetlán, provincia de Soconusco, a los cuales encargamos y mandamos en virtud de santa obediencia tengan especial cuidado de nos avisar de los transgresores y pecadores públicos y por las dichas sus vitas [sic] hubiere que castigar, y de cómo se guarda esta santa sinodal.

Las cuales dichas constituciones fueron leídas y publicadas por mí, Lope de Villalobos, notario público y apostólico en esta ciudad y Obispado, en la santa iglesia catedral de esta ciudad de Santiago de Guatemala, Indias del Mar Océano, en tres días que fueron los que duró el dicho santo sínodo, uno en pos de otro que el postrero de ellos cumplió a 15 días del mes de octubre, año del nacimiento de nuestro salvador Jesucristo de 1566 años, en presencia y por mandado del muy ilustrísimo y reverendísimo señor Bernardino de Villalpando, obispo de esta ciudad, del Consejo de su majestad, y del ilustre gobernador de su majestad, licenciado Francisco Briceño, y en presencia de los señores deán y Cabildo de la dicha santa iglesia, y de los provinciales y religiosos de las órdenes, y de otros muchos clérigos, curas y vicarios de este Obispado que aquí firmaron sus nombres y prometieron de guardar y cumplir todo lo contenido en las dichas sinodales, so las penas en ellas puestas, y en presencia del procurador de esta ciudad, Gasco [i?] de Herrera, y de otros muchos caballeros y ciudadanos, siendo presentes por testigos don Francisco de la Cueva, Juan de Guzmán el secretario, Diego de Robledo fator, Francisco de Ovalle teniente de tesorero, Gregorio de Polanco, y Alonso de Rosales contador, oficiales de su majestad, y Carlos Bonifaz y Santos de Figueroa, alcaldes ordinarios, Diego de Bivar, alguacil mayor de esta ciudad, y otros muchos vecinos y ciudadanos.

Episcupus Cuauhtemalen y el arcediano y el chantre y el canónigo Cepeda, el licenciado [Francisco] Cambranes, Gaspar López, Juan Méndez, Alonso Dávila, Pedro Rodríguez, Baltasar de Vera, el bachiller Alonso López, Martín Bueno, Juan Arias de Vera, Hernán Pérez, Francisco Martínez, el licenciado Salvatierra, Juan de Villafaña, Jerónimo

${ }^{61}$ Vocablo en interlínea. 
Romero, Juan Tello, Bartolomé Núñez de Valdespino, Josepe Sanpol, Tomás de Lersundi, Juan Mateos e testigo [¿?], Diego Cornejo.

Yo Lope de Villalobos, notario público y apostólico en esta ciudad y Obispado, presente fui a lo que dicho es y ante mí pasó, con los dichos testigos. Y de mandamiento de su reverendísima los recibí y leí y publiqué en alta voz inteligible, subido en un púlpito de la dicha santa iglesia, en fe de lo cual fiz aquí este mi signo, que va tal en testimonio de verdad, Lope de Villalobos, notario.

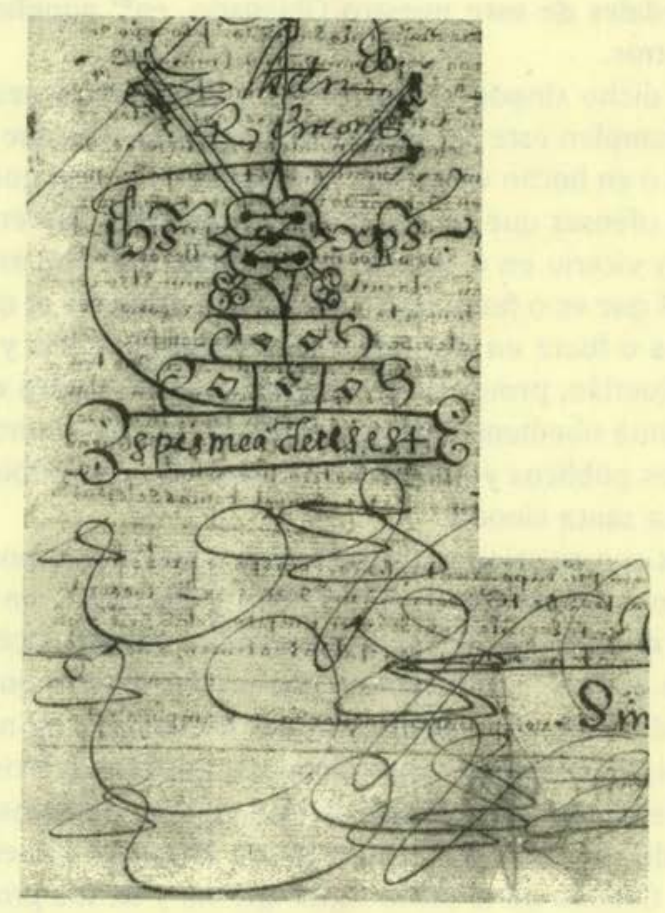

Y después de lo susodicho, su señoría reverendísima dijo que para que sea guardado y cumplido este [f $16 \mathrm{v}$ ] santo sínodo por él celebrado, y no puedan pretender ignorancia los dichos sus curas y vicarios, mandaba y mandó a todos y cada uno de ellos, dentro de un mes, cada uno lleve un tanto del notario autorizado, al cual dará por sus derechos cinco pesos de oro en que lo tasamos, a costa de las fábricas de las iglesias de sus partidos, para que siempre quede en las dichas iglesias, para que por él los curas que son o fueren se rijan guardando el dicho santo sínodo y otro ninguno lo pueda dar autorizado, y lo firmó de su nombre.

Episcopus Cuauhtemalen.

Y después de lo susodicho, en la dicha ciudad de Santiago de Guatimala, en 22 días del mes de octubre de 1566 años, su señoría reverendísima dijo que para que ninguno de los dichos curas y vicarios y rectores de este Obispado pretenda ignorancia, porque conforme al santo Concilio Tridentino, sesión 2, cuarto capítulo, todos los curas deban 
tener libros en sus iglesias en que con día, mes y año asienten los que casaren, mandaba y mandó a todos los dichos curas y rectores, guardando el dicho Santo Concilio, así lo hagan y cumplan, por ser cosa muy conveniente y necesaria entre estos naturales y españoles. Lo cual cumplan so pena que el que fuere hallado sin el dicho libro incurra en pena de 50 pesos por la primera vez, aplicados por tres partes, la tercia para la Cámara de su señoría y la tercia para el juez que lo sentenciare y la tercia para el acusador, y por la segunda vez la pena de 100 pesos, aplicados según dichas y, por la tercera, privación de beneficio. Y lo firmó de su nombre.

Episcopus Cuauhtemalen ${ }^{62}$

${ }^{62}$ El texto concluye con la certificación de autenticidad del traslado, dada por el notario Lope de Villalobos. 


\section{BIBLIOGRAFÍA}

Archivo General de Indias, Patronato 182, R. 24. "Oposición a varios artículos del sínodo de Guatemala. Expediente promovido por Diego Ramírez, fiscal de la Audiencia de Guatemala, oponiéndose a varios artículos del sínodo celebrado los días 12 y 13 de octubre de 1566 por el obispo Bernardino de Villalpando".

Diccionario de Autoridades

1990 Madrid: Gredos (4a reimpresión en tres tomos, facsimilar de la de 1737).

Eguiara y Eguren, Juan José de

1986 Biblioteca mexicana, E. de la Torre Villar (ed.). México: UNAM.

Estrada Monroy, Agustín

1972 Datos para la historia de la Iglesia en Guatemala. Guatemala: Sociedad de Geografía e Historia, 3 vols.

Gálvez G., María Albertina

1963 "Nota prologal" a las Cartas y testamento de Francisco Marroquín, pp. VII-XX. Guatemala: Editorial José de Pineda Ibarra del Ministerio de Educación Pública (Biblioteca guatemalteca de cultura popular).

García Peláez, Francisco de Paula

1943 Memorias para la Historia del antiguo Reino de Guatemala. Guatemala: Tipografia Nacional, 3 tomos.

González Dávila, Gil

1982 Teatro eclesiástico de la primitiva Iglesia de las Indias Occidentales. México: Centro de Estudios de Historia de México de Condumex (ed. facsimilar de la de 1649).

Juarros, Domingo

1981 Compendio de la historia del Reino de Guatemala. Guatemala: Editorial Piedra Santa.

MacLeod, Murdo J.

1980 Historia socioeconómica de la América Central española, 1520-1720. Guatemala: Editorial Piedra Santa.

Moliner, María

1988 Diccionario de uso del español. Madrid: Gredos, 2 vols.

Núñez de la Vega, Francisco

1988 Constituciones diocesanas del obispado de Chiapa (1702), Estudio introductorio, modernización, notas y apéndices de M.C. León y M. H. Ruz. México: UNAM, IIFL, Centro de Estudios Mayas (Serie Fuentes para el estudio de la cultura maya: 6).

O'Flaherty, Edward

1984 Iglesia y sociedad en Guatemala (1524-1563). Análisis de un proceso cultural. Sevilla: Publicaciones de la Universidad de Sevilla.

Pardo, José Joaquín

1984 Efemérides de la Antigua Guatemala, 1541-1779. Guatemala: AGCA, BNG, IAH, CNPA, $3^{\text {a }}$ ed.

Recopilación de leyes de los reynos de Las Indias

1987 México: Miguel Angel Porrrúa-Escuela Libre de Derecho, edición facsimilar de la príncipe (1681) en 5 vols. 
Remesal, Antonio de

1966 Historia general de las Indias Occidentales y particular de la gobernación de Chiapa y Guatemala, Prólogo de A. Batres. Guatemala: Editorial José de Pineda Ibarra, $3^{a}$ ed. en 4 vols. (Colección Biblioteca guatemalteca de cultura popular).

1988 Historia general de las Indias Occidentales y particular de la gobernación de Chiapa y Guatemala, edición y estudio preliminar de C. Sáenz de Santa María. México: Porrúa, 2 vols.

Ricard, Robert

1933 La "conquête spirituelle" du Mexique. Essai sur l'apostolat et les mèthodes missionnaires des Ordres Mendiants en Nouvelle-Espagne de 1523 à 1572. Paris: Institut d'Ethnologie.

Ruz, Mario Humberto et al.

2002 Memoria eclesial guatemalteca. Las visitas pastorales, vol. I (Siglo xvı). México: Conacyt, UNAM y Arzobispado Primado de Guatemala.

2004 Memoria eclesial guatemalteca. Las visitas pastorales, vol. III (1719-1724). México: Conacyt, UNAM y Arzobispado Primado de Guatemala.

Ruz, Mario Humberto, Antonio de Paz y Raquel Vicencio

En preparación Libros del Cabildo Eclesiástico del obispado de Guatemala (1537-1648), t. I y II, México: UNAM.

Solís Robleda, Gabriela

2003 Bajo el signo de la compulsión. El trabajo forzoso indigena en el sistema colonial yucateco, 1540-1730. México: CIESAS, ICY, Conaculta-INAH y Miguel Ángel Porrúa (Colección Peninsular).

Solís Robleda, Gabriela y Paola Peniche (eds.)

1996 Idolatría y sublevación. Mérida: Universidad Autónoma de Yucatán (Documentos para la historia indígena de Yucatán: 1).

Van Oss, Adriaan C.

1986 Catholic colonialism. A parish history of Guatemala, 1524-1821. Cambridge: Cambridge University Press.

Vázquez, fray Francisco

1937 Crónica de la provincia del Santísimo Nombre de Jesús de Guatemala, Ed. de L. Lamadrid. Guatemala: Sociedad de Geografia e Historia, $2^{\text {a }}$ ed. en 4 vols.

Ximénez, fray Francisco

1999 Historia de la provincia de San Vicente de Chiapa y Guatemala, de la Orden de Predicadores. Guatemala: Sociedad de Geografía e Historia, $2^{\mathrm{a}}$ ed. en 5 vols. 